\section{SANDIA REPORT}

SAND97-2317 • UC-2040

Unlimited Release

Printed September 1997 oct 15998

$08 \mathrm{TI}$

\title{
TDR Calibration for the Alternative Landfill Cover Demonstration (ALCD)
}

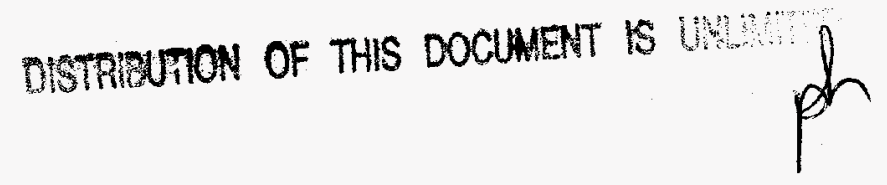

Jesus Lopez, Stephen F. Dwyer, James N. Swanson

Prepared by

Sandia National Laboratories

Albuquerque, New Mexico 87185 and Livermore, California 94550

Sandia is a multiprogram laboratory operated by Sandia Corporation, a Lockheed Martin Company, for the United States Department of

Energy under Contract DE-AC04-94AL85000.

Approved for public release; distribution is unlimited.

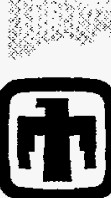

Sandia National Laboratories 
Issued by Sandia National Laboratories, operated for the United States Department of Energy by Sandia Corporation.

NOTICE: This report was prepared as an account of work sponsored by an agency of the United States Government. Neither the United States Government nor any agency thereof, nor any of their employees, nor any of their contractors, subcontractors, or their employees, makes any warranty, express or implied, or assumes any legal liability or responsibility for the accuracy, completeness, or usefulness of any information, apparatus, product, or process disclosed, or represents that its use would not infringe privately owned rights. Reference herein to any specific commercial product, process, or service by trade name, trademark, manufacturer, or otherwise, does not necessarily constitute or imply its endorsement, recommendation, or favoring by the United States Government, any agency thereof, or any of their contractors or subcontractors. The views and opinions expressed herein do not necessarily state or reflect those of the United States Government, any agency thereof, or any of their contractors.

Printed in the United States of America. This report has been reproduced directly from the best available copy.

Available to DOE and DOE contractors from

Office of Scientific and Technical Information

P.O. Box 62

Oak Ridge, TN 37831

Prices available from (615) 576-8401, FTS 626-8401

Available to the public from

National Technical Information Service

U.S. Department of Commerce

5285 Port Royal Rd

Springfield, VA 22161

NTIS price codes

Printed copy: A04

Microfiche copy: A01 


\title{
TDR Calibration for the Alternative Landfill Cover Demonstration (ALCD)
}

\author{
Jesus Lopez, Stephen F. Dwyer, and James N. Swanson \\ Environmental Restoration Technologies Department. \\ Sandia National Laboratories \\ P.O. Box 5800 \\ Albuquerque, NM 87185-0719
}

\begin{abstract}
The Alternative Landfill Cover Demonstration is a large scale field test that compares the performance of various landfill cover designs in dry environments. An important component of the comparison is the change in the moisture content of the soils throughout the different cover test plots. Time Domain Reflectometry (TDR) is the primary method for the measurement of the volumetric moisture content. Each of the covers is composed of layers of varying types and densities of soils. The probes are therefore calibrated to calculate the volumetric moisture content in each of the different soils in order to gain the optimum performance of the TDR system. The demonstration plots are constructed in two phases; a different probe is used in each phase. The probe that is used in Phase $I$ is calibrated for the following soils: compacted native soil, uncompacted native soil, compacted native soil mixed with six percent sodium bentonite by weight, and sand. The probe that is used in Phase $I$ is calibrated for the following soils: compacted native soil, uncompacted native soil, and sand. In addition, the probes are calibrated for the varying cable lengths of the TDR probes. The resulting empirically derived equations allow for the calculation of in-situ volumetric moisture content of all of the varying soils throughout the cover test plots in the demonstration.
\end{abstract}


Intentionally Left Blank 


\section{DISCLAIMIER}

Portions of this document may be illegible in electronic image prodnets. Images are produced from the best available original document. 


\section{Contents}

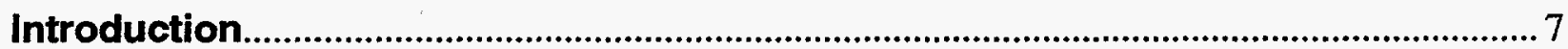

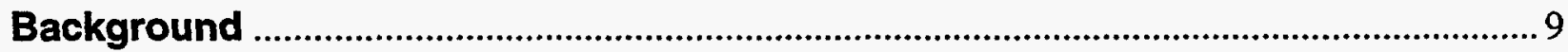

Soil Measurements With Time Domain Reflectometry .............................................. 11

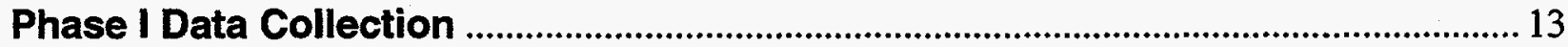

6\% Bentonite Soil and Compacted Native Soil .............................................................. 13

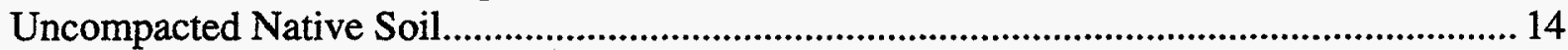

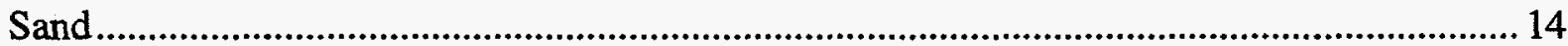

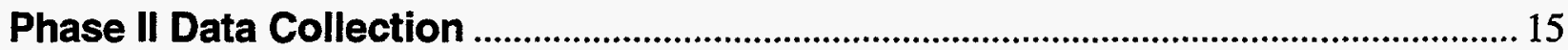

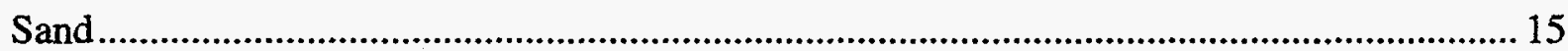

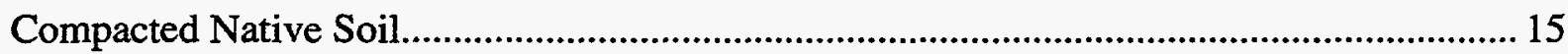

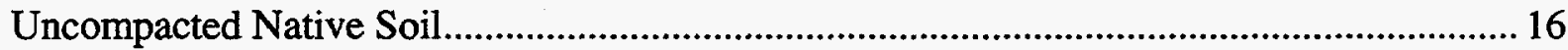

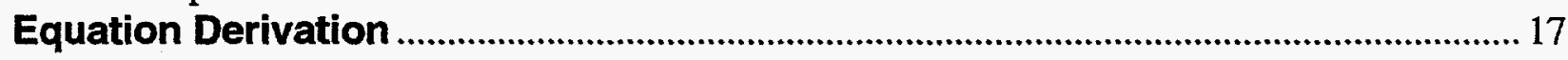

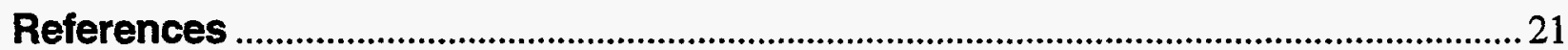

\section{Figures}

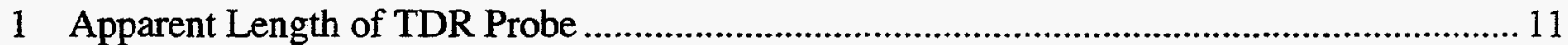

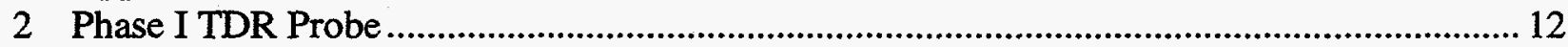

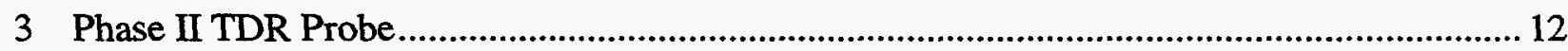

\section{Appendices}

Appendix A: Plots of Third Order Polynomials for Individual Cable Lengths. A-1

Appendix B: Volumetric Moisture Content Calculations. B-1 
Intentionally Left Blank 


\section{Introduction}

The effectiveness of current EPA landfill cover designs is being questioned, especially in the southwestern states of the United States. The Alternative Landfill Cover Demonstration is a large scale field test to determine the effectiveness of the current accepted designs and compare the results to those of alternative landfill cover designs. The purpose of the demonstration is to determine which cover is the most effective based on cost, ease of construction, and performance. One of the variables being compared in the performance area is the moisture content of the soils in the covers. Time domain reflectometry (TDR) probes measure the moisture content of the soils in each cover. However, an extensive calibration of the probes is required before useful data can be obtained from the probes. Once the calibration is complete, TDR probes provide a means of measuring in-situ volumetric moisture content of soils which allows for a thorough comparison of the various landfill covers.

The following report describes the procedure that is used to calibrate all of the TDR probes used in the Alternative Landfill Cover Demonstration. 
Intentionally Left Blank 


\section{Background}

The Alternative Landfill Cover Demonstration (ALCD), currently underway at Sandia National Laboratories in Albuquerque, New Mexico, is a large scale landfill cover field test. In the demonstration, six landfill cover test plots are constructed side-by-side to compare the plots based on their respective costs, ease of construction, and performance. The construction of the plots is divided into two phases. In Phase I, two covers meeting minimum RCRA Subtitle ' $C$ ' and Subtitle ' $D$ ' requirements, respectively, are constructed along with Alternative Cover Number one, designed for dry environments. In Phase II, Alternative Covers Two, Three, and Four, which are specifically designed for dry environments, are constructed. The Subtitle ' $C$ ' and Subtitle ' $\mathrm{D}$ ' plots serve as a baseline to compare against the alternative designs in Phase I and Phase $I$. The results of the field test indicate which of the landfill cover designs is most effective for dry environments.

While the designs of the covers differ, the size and test conditions are the same for all of the test plots. Each of the plots is one hundred meters long and thirteen meters wide; all plots are separated by eleven meters. The plots are situated lengthwise along the east-west axis. Each cover slopes five percent from the middle of the plot fifty meters to the ends of the plot; the layers within each cover design have the same five percent slope. The orientation of the plots allows for passive and active monitoring of the test plots. The western slopes of the plots are monitored under ambient conditions - passive monitoring. A sprinkler system installed in the eastern slopes of the plots allows for stress tests (i.e., simulation of a one hundred year storm) active monitoring. The similar conditions of the plots allows for an equitable comparison of the cover designs.

All test cover plots are instrumented to quantify water balance variables and ancillary information. For example, various instrumentation installed in and around the covers allows for the continuous collection of the following data: soil moisture status, percolation and interflow, runoff, precipitation, wind speed and direction, relative humidity, and air and soil temperature. The data collection system is automated with manual backup for each individual instrumentation system. Also, periodic measurements will be obtained on vegetation cover, biomass, leaf area index, and species composition. The collection of all such data is tantamount in making a comprehensive comparison of the covers.

The success of the demonstration is heavily dependent on the monitoring systems and care taken prior to and during their installation; as well as follow-on maintenance. One example of care taken prior to the installation is the calibration of the Time Domain Reflectometry (TDR) probes used to determine soil moisture status. TDR is the process of sending pulses through a cable and observing the reflected waveform. If a waveguide, such as a steel rod, is placed on the end of a cable, the reflected waveform is influenced by the dielectric constant of the material surrounding the waveguide. In soils, the dielectric constant of the soil is greatly influenced by the amount of water in the soil; therefore, the reflected waveform from a TDR probe in soil is altered by the moisture content of the soil. The dielectric constant of the soil can be related to the volumetric water constant of the soil in a mathematical expression; thus, a TDR probe can be used to determine in-situ soil moisture content. However, the probes must be carefully calibrated 
before they are installed. Different types of soils reflect different waveforms at similar moisture contents. Therefore, a careful calibration of the TDR probes is required before the probes are installed in the test plots in order to ensure the high level of performance required from the monitoring system. 


\section{Soil Measurements With Time Domain Reflectometry}

Soil moisture measurements are made using TDR, a process of sending pulsed waveforms through a coaxial cable to a fixed length probe and observing the reflected waveform. The reflected waveform is analyzed for two distinct points: the beginning of the probe and the end of the probe. The distance between the two points is identified as the apparent length of the probe (See Figure 1). The apparent length of the probe is proportional to the square root of the apparent dielectric constant of the soil. Because the dielectric constant of water is relatively high in comparison to other medium, a signal will propagate slower in a wetter media (i.e., soil) than in the same medium when dry; therefore, probes in soils with a high moisture content have a longer apparent length than do probes in drier soils. Further, a mathematical relationship between the volumetric moisture content of the soil and the apparent probe length obtained from the waveform can be established. The resulting equation provides a tool for in-situ volumetric soil moisture content measurements using a time domain reflectometry system.

The TDR system that is used in the Alternative Landfill Cover Demonstration (ALCD) consists of Sandia designed and built probes in conjunction with Campbell Scientific's TDR Soil Moisture System for Phase I. Phase II of ALCD uses Campbell Scientific designed and built TDR probes in conjunction with the same CR10 system.

The main components of Campbell Scientific's TDR Soil Moisture System are a Tektronix 1502B cable tester and a CR10 measurement and control system. The use of the 1502B in conjunction with the CR10 allows for the greatest flexibility in the TDR system. The CR10 contains several different algorithms for wave analysis. For example, the CR10 can measure and store entire waveforms, electrical conductivity, or the ratio of apparent length to actual length of the probe. For demonstration purposes, the CR10 is programmed to output the ratio of the apparent length of the rods to the actual length of the rods $\left(\mathrm{L}_{\mathrm{a}} / \mathrm{L}\right)$; volumetric moisture contents are calculated from the ratio in a separate algorithm.
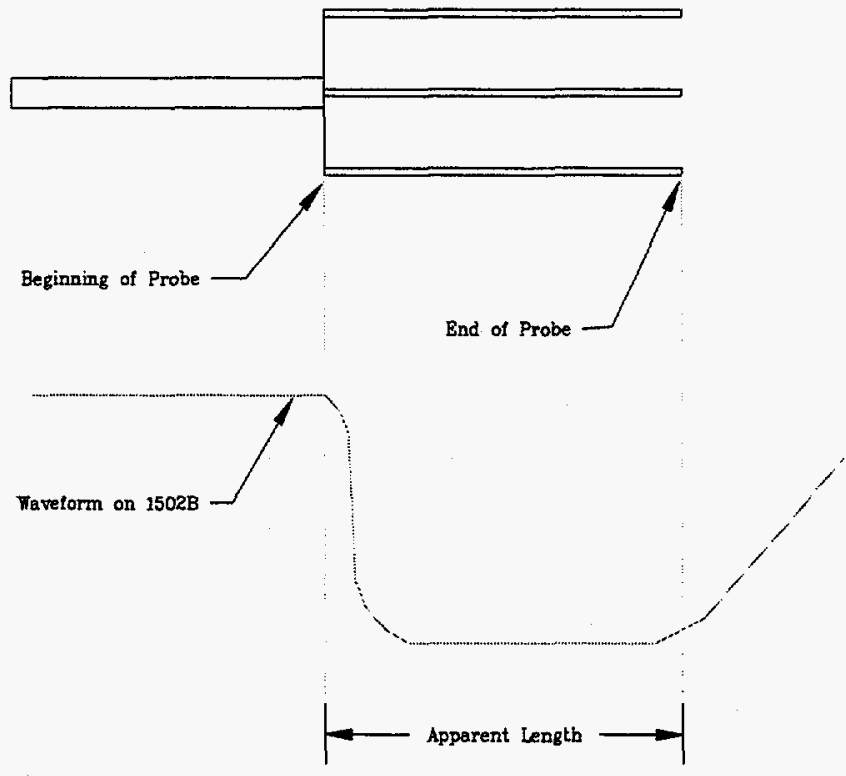

Figure 1. Apparent Length of TDR Probe 
The TDR probes for Phase I are a product of extensive research conducted at Sandia National Laboratories. During the design of Phase I, commercially available probes reflect a waveform that can not be used. The waveform does not show a rise when the signal reaches the end of the probe; therefore, the end point of the wave can not be determined and a new probe is required. Components of the probe, such as rod length, rod spacing, number of rods (two or three), coating the rods (with several different types of coatings, coating thickness, and surface preparation), rod diameter, and diode installments are varied until the optimum probe is developed. The resulting probes consist of a potted PVC housing with a length of RG-8 coax cable connected to three equally spaced, six inch long exposed length, epoxy coated prongs (See Figure 2). The center prong is connected to the signal propagating conductor, while the two outside prongs are connected to the coax shield. The epoxy coating inhibits conductivity arising from saline conditions in highly compacted, wet soils. This condition greatly reduces the amplitude of the signal, making meaningful measurements of the time domain difficult to obtain which is a problem in the commercially available probes.

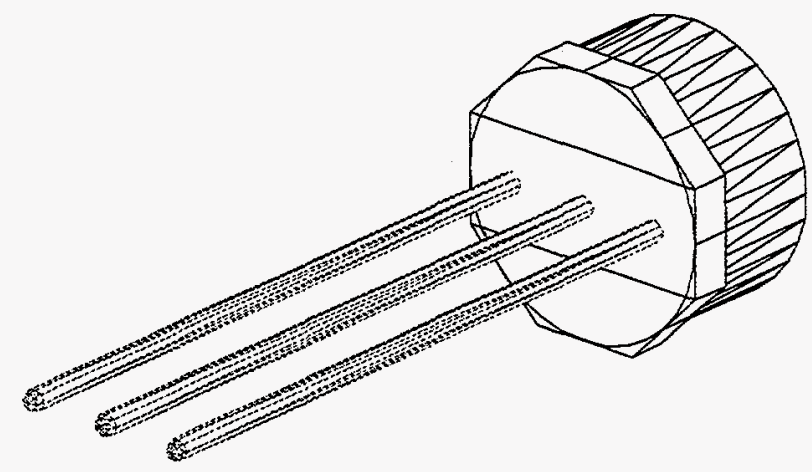

Figure 2. Phase I TDR Probe

When Phase II is in the design phases, Campbell Scientific releases a TDR probe that is capable of reflecting waveforms in the various soils used in the Phase II test plots. In order to conserve the resources used in constructing more probes, the TDR probes for Phase II are designed by and purchased from Campbell Scientific (See Figure 3). The probes consist of a length of RG-8 coaxial cable terminating in an epoxy body. Within the epoxy body, the center conductor of the cable is connected to the center rod of the three parallel $3 / 16$ inch diameter, twelve inch long stainless steel rods. The shield of the coaxial cable is attached to the two outside rods. The rods on the Campbell Scientific probes are not coated due to the increased resolution of the longer rods and the lack of sodium bentonite in the soils producing better defined waveforms.

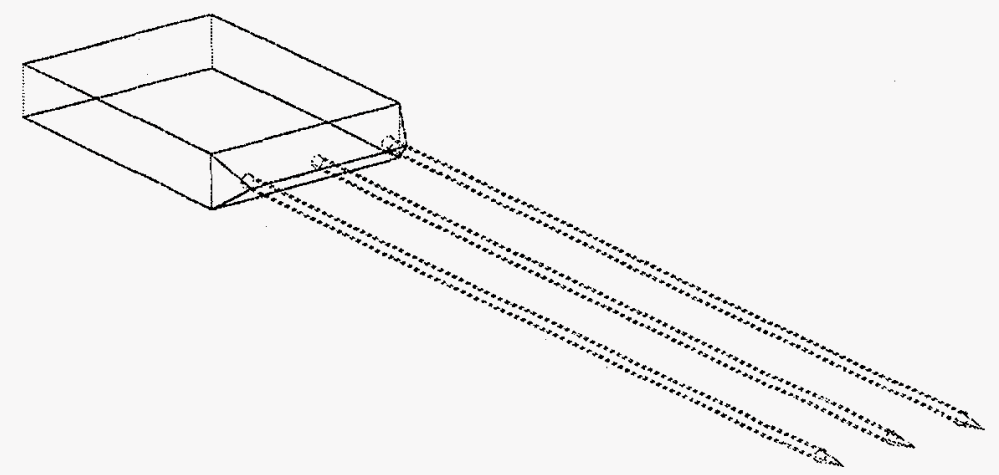

Figure 3. Phase II TDR Probe 


\section{Phase I Data Collection}

Various external variables may alter the CR10's analysis of the waveform; therefore, the calibration process requires that the most significant variables be identified and accounted for in the procedure. After several preliminary measurements, two variables are identified to have the greatest impact on the waveform and the CR10's analysis: soil type and cable length. The TDR probes for ALCD, Phase I are placed in four distinct soils: compacted soil mixed with $6 \%$ bentonite (by weight), sand, compacted native soil and uncompacted native soil. The CR10 records a different $L_{a} / L$ ratio for similar moisture contents; therefore, calibration data is collected for each of the different soils in Phase I. Furthermore, the total cable length of each probe affects the waveform and the resulting $\mathrm{L}_{\mathrm{a}} / \mathrm{L}$ value. After examining the cable lengths that are required for the various soil types in each plot, five cable lengths are identified to adequately represent the entire array of cable lengths; therefore, coaxial cables are prepared to allow for the following lengths: 59', 82', 98', 120', and 138'. In the resulting calibration procedure, data is collected for each of the five cable lengths within each soil type.

To achieve proper soil compaction, a customized mold is designed and manufactured. The mold is similar to a Proctor mold; however, the diameter of the mold is 7.75 inches, and the height is 5.25 inches. Also, a fitting for a TDR probe is built into the mold. The fitting holds the PVC housing of the TDR probes in place while soil is compacted around the probe rods in the mold. The fitting prevents any probe movement and prevents damage that would occur to the probe rod coating if the probe is forced into a compacted brick of soil. A thin PVC pipe is cut to fit within the mold and around the probe. The PVC pipe prevents the metal mold from altering the TDR signal. The custom mold allows for similar compaction and soil conditions to be achieved throughout the entire calibration procedure.

\section{6\% Bentonite Soil and Compacted Native Soil}

Throughout the calibration procedure, representative field conditions are simulated. Therefore, samples of each of the soils are taken from their respective stockpiles at the construction site and are sieved with a number 4 sieve. The resulting soil is then placed in the mold with four equal lifts. The customized mold is approximately twice the size of the standard Proctor mold; therefore, each lift is delivered 56 blows, more than twice the amount required for a standard Proctor test, with a standard Proctor Compaction hammer. The TDR probe is placed in the mold between the second and third lifts. Once compaction is complete, the excess soil is shaved from the top of the mold so that the height of soil in the mold is level with the top of the mold. While ten $\mathrm{L}_{\mathrm{a}} / \mathrm{L}$ values are recorded by the CR10, the soil sample is weighed. Once the ten values are collected, the soil sample is broken apart, and a sample of soil is taken from around the probes and dried to determine gravimetric moisture content of the soil per ASTM D4643. Water is then added to the soil, and the soil is mixed again to achieve a homogeneous sample. The procedure is repeated for five different gravimetric water contents ranging from $1.4 \%$ to $18 \%$. After ten $\mathrm{L}_{a} / \mathrm{L}$ values are obtained for each of the five different water contents, the cable length is changed and the procedure is repeated for each of the five different cable lengths. 


\section{Uncompacted Native Soil}

A similar procedure is repeated for the uncompacted native soil. Samples of soil are taken from the stockpile in the field and sieved with a number 4 sieve. The TDR probe is secured into the mold while the soil is placed in the mold and slightly compacted at varying intervals. An inconsistent procedure of compaction simulates field conditions. Once "compaction" is complete, the excess soil is shaved from the top of the mold so that the height of soil in the mold is level with the top of the mold. Ten $\mathrm{L}_{\mathrm{a}} / \mathrm{L}$ values are recorded by the CR10, and then the soil sample is weighed. The soil sample is then broken apart, and a sample of soil is taken from around the probes and is dried to determine gravimetric moisture content of the soil per ASTM D4643. Water is then added to the soil, and the soil is mixed again to achieve a homogeneous sample. The procedure is repeated for five different gravimetric water contents ranging from $1.4 \%$ to $18 \%$. When $\mathrm{L}_{\mathrm{a}} / \mathrm{L}$ values are obtained for the five different water contents, the cable length is changed and the procedure is repeated for the five different cable lengths.

\section{Sand}

Samples of sand are also taken from the stockpile in the field. The TDR probe is secured into the mold while the sand was placed in the mold and slightly compacted at varying intervals. An inconsistent procedure of compaction is used to simulate field conditions. Once compaction is complete, the excess soil is shaved from the top of the mold so that the height of soil in the mold is level with the top of the mold. Ten $\mathrm{L}_{2} / \mathrm{L}$ values are recorded by the CR10, then the soil sample is weighed. A sample of soil is taken from around the probes and dried to determine gravimetric moisture content of the soil per ASTM D4643. Water is then added to the soil, and the soil is mixed again to achieve a homogeneous sample. The procedure is repeated for five different gravimetric water contents ranging from $1.4 \%$ to $18 \%$. When $\mathrm{L}_{2} / \mathrm{L}$ values are obtained for the five different water contents, the cable length is changed and the procedure is repeated for the five different cable lengths. 


\section{Phase II Data Collection}

As in Phase I, soil type and cable length are the most significant variables in affecting the CR10's analysis of the waveform. Therefore, data is collected for the three types of soils in Phase II: sand, compacted native soil, and uncompacted native soil. Also, data is collected for five representative cable lengths, $85,102,119,138$, and 156 feet, for each type of soil.

In order to achieve proper compaction of the soil, a mold is designed and built at Sandia National Laboratories to accommodate the larger Phase II probe. The mold is constructed from a one quarter inch steel plate with the following dimensions: 9 inches wide by 24 inches long by 6 inches deep. This size mold allows the entire Phase II probe to lie flat; consequently, a fitting is not required to hold the probe in place. Soil is compacted around the entire probe within the mold.

\section{Sand}

Samples of sand are also taken from the stockpile in the field. The TDR probe is secured into the mold while the sand is placed in the mold and slightly compacted at varying intervals. An inconsistent procedure of compaction is used to simulate field conditions. Once compaction is complete, the excess soil is shaved from the top of the mold so that the height of soil in the mold is level with the top of the mold. Ten $\mathrm{L}_{\mathrm{a}} / \mathrm{L}$ values are recorded by the $\mathrm{CR} 10$, then the soil sample is weighed. A sample of soil is taken from around the probes and is dried in order to determine gravimetric moisture content of the soil per ASTM D4643. Water is then added to the soil, and the soil was mixed again to achieve a homogeneous sample. The procedure is repeated for the following approximate gravimetric water contents: $1.5 \%, 5 \%, 7 \%, 11 \%$, and $15 \%$. For Phase II, the cables used to connect the probes to the $1502 \mathrm{~B}$ are constructed so that the probe would not have to be removed from the soil when the cable lengths were changed. Therefore, the five moisture contents are the same for all cable lengths within each soil type.

\section{Compacted Native Soil}

Throughout the calibration procedure, field conditions are simulated as close as reasonably possible. Therefore, samples of each of the soils are taken from their respective stockpiles at the construction site and are sieved with a number 4 sieve. The resulting soil is then placed in the mold with three equal lifts. As that the customized mold is of an unusual size and shape, tests are conducted to determine the number of blows required from a Standard Proctor hammer in order to achieve $95 \%$ compaction; the result is 256 blows per lift. The TDR probe is placed in the mold in the middle of the second lift. Once compaction is complete, the excess soil is shaved from the top of the mold so that the height of soil in the mold is level with the top of the mold. After ten $\mathrm{L}_{\mathrm{a}} / \mathrm{L}$ values are recorded by the $\mathrm{CR} 10$, the soil sample is weighed. Once the ten values are collected, the soil sample is broken apart, and a sample of soil is taken from around the probes and is dried to determine gravimetric moisture content of the soil per ASTM D4643. Water is then added to the soil, and the soil is mixed again to achieve a homogeneous sample. The procedure is repeated for the following approximate gravimetric water contents: $1.5 \%, 5 \%$, $7 \%, 11 \%$, and $15 \%$. For Phase $I$, the cables used to connect the probes to the $1502 \mathrm{~B}$ are 
constructed so that the probe would not have to be removed from the soil when the cable lengths are changed. Therefore, the five moisture contents are the same for all cable lengths within each soil type.

\section{Uncompacted Native Soil}

A similar procedure is repeated for the uncompacted native soil in Phase II as in Phase I. Samples of soil are taken from the stockpile in the field and are sieved with a number 4 sieve. The soil is place in the mold with three lifts. The TDR probe is placed in the mold in the middle of the second lift. Each lift receives 200 blows with a Standard Proctor Hammer to simulate field conditions. Once "compaction" is complete, the excess soil is shaved from the top of the mold so that the height of soil in the mold is level with the top of the mold. Ten $\mathrm{L}_{a} / \mathrm{L}$ values are recorded by the CR10, and then the soil sample is weighed. The soil sample is then broken apart, and a sample of soil is taken from around the probes and dried to determine gravimetric moisture content of the soil per ASTM D4643. Water is then added to the soil, and the soil is mixed again to achieve a homogeneous sample. The procedure is repeated for the following approximate gravimetric water contents: $1.5 \%, 5 \%, 7 \%, 11 \%$, and $15 \%$. For Phase II, the cables used to connect the probes to the 1502B are constructed so that the probe would not have to be removed from the soil when the cable lengths are changed. Therefore, the five moisture contents are the same for all cable lengths within each soil type. 


\section{Equation Derivation}

The first step in developing the equations is to convert the data into volumetric soil moisture contents (See Appendix B). The gravimetric moisture content, total mass of the sample, and volume of the sample are known variables, the volumetric moisture content is therefore determined from the following equation:

$$
\begin{gathered}
\theta_{v}=\frac{w M_{t}}{(1+w) V_{t}} \\
\text { where: } \theta_{v}=\text { Volumetric Moisture Content } \\
w=\text { Gravimetric Moisture Content } \\
M_{t}=\text { Total Mass of Sample } \\
V_{t}=\text { Total Volume of Sample (Mold) }
\end{gathered}
$$

Once the volumetric moisture content for all of the tests is calculated, the ten $\mathrm{L}_{\mathrm{a}} / \mathrm{L}$ values recorded by the CR10 are averaged for each moisture level. The five volumetric water contents are plotted against the resulting average $\mathrm{L}_{\mathrm{a}} / \mathrm{L}$ value for each cable length on an Excel ${ }^{\mathrm{TM}}$ spreadsheet. Using the "Insert Trend Line" feature on Excel, a third order polynomial is found to be the best fit for the data (See Appendix A). After a polynomial for each individual cable length is determined, the data from all of the cable lengths in each soil type is plotted on one graph to verify that separate equations are required for the various cable lengths. Upon examination, the data on the plot containing all of the ratios from the various cable lengths is more scattered than on the plots for individual cable lengths; therefore, the third order polynomial that fit all of the data does not have as high a correlation as the polynomials that fit the data for individual cable lengths. It is therefore apparent that separate polynomials are required for the five different cable lengths in the majority of the soils. The sand, however, only requires two equations: one for the shortest cable and another for the remaining four lengths in Phase I. In Phase II, only one equation is required for sand. The remaining soils require five separate equations. The resulting equations allow for the determination of the volumetric moisture content of the various soils throughout the test plots for the Alternative Landfill Cover Demonstration.

\footnotetext{
${ }^{n M}$ Excel is a registered trademark of Microsoft.
} 
Intentionally Left Blank 


\section{Conclusion}

TDR probes are a key element in the comparison of the six test plots in the Alternative Landfill Cover Demonstration. However, the probes must be calibrated for their specific type of soil and cable length in order to obtain useful data from the TDR measurements. When calibration is complete, the TDR probes provide a reliable measurement of in-situ volumetric moisture content of the soils that are used throughout the Alternative Landfill Cover Demonstration. 
Intentionally Left Blank 


\section{References}

ASTM D-4643. Determination of water (moisture) content of soil by microwave oven method.

Campbell Scientific, Inc. 1992. Addendum to: campbell scientific tdr soil moisture measurement system manual. CR10 Measurement and Control Module Operator's Manual.

Dasberg, S., and J.W. Hopmans. 1992. Time domain reflectometry calibration for uniformly and nonuniformly wetted sandy and clayey loam soils. Soil Sci. Soc. Am. J. 56:1341-1345.

Dirksen, C., and S. Dasberg. 1993. Improved calibration of time domain reflectometry soil water content measurements. Soil Sci. Soc. Am. J. 57:660-667.

Heimovaara, T.J., and W. Bouten. 1990. A computer-controlled 36-channel time-domain reflectometry system for monitoring soil water contents. Water Resour. Res. 27:857-864. 
Intentionally Left Blank 


\section{Appendix A}

Plots of Third Order Polynomials for Individual Cable Lengths 
Intentionally Left Blank 
6\% Bentonite, Phase I, 59' Cable

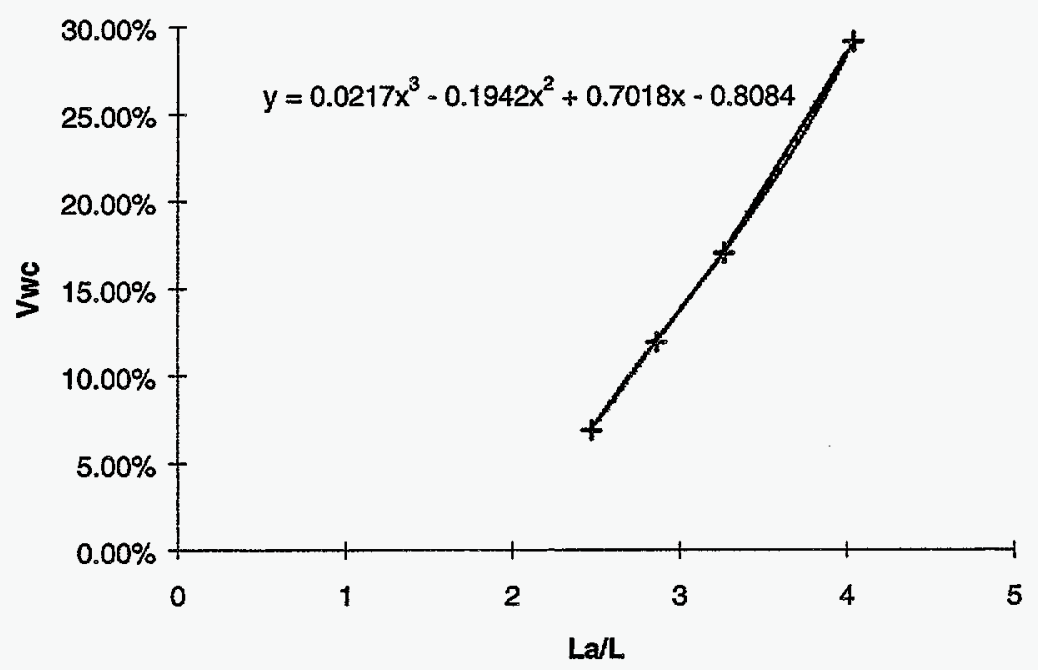

Figure A-1

6\% Bentonite, Phase I, 82' Cable

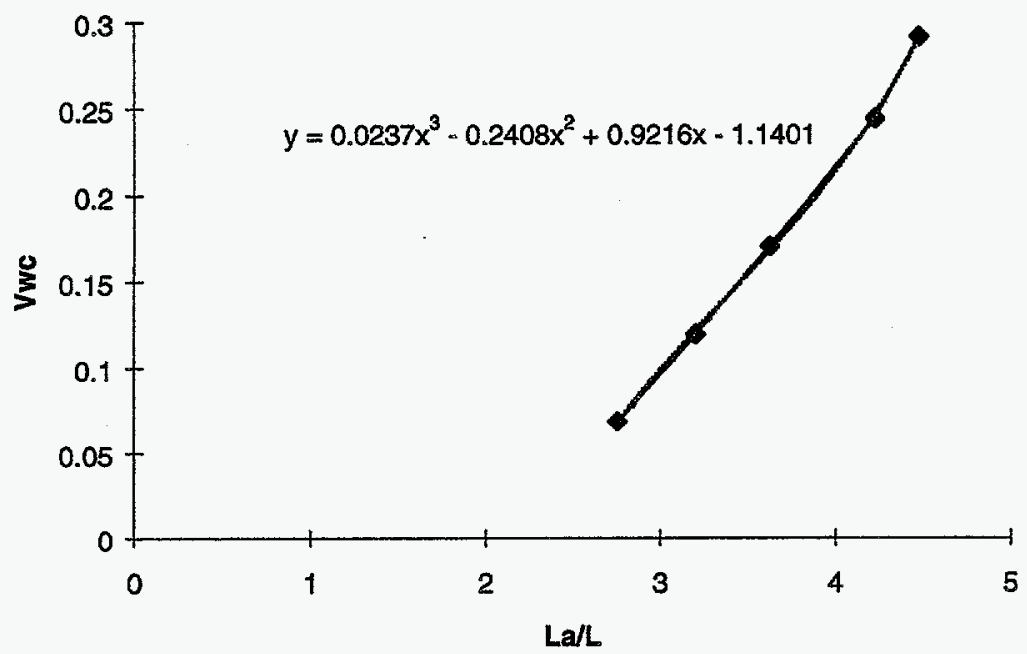

Figure A-2 
Intentionally Left Blank

A-4 
$6 \%$ Bentonite, Phase I, 98' Cable

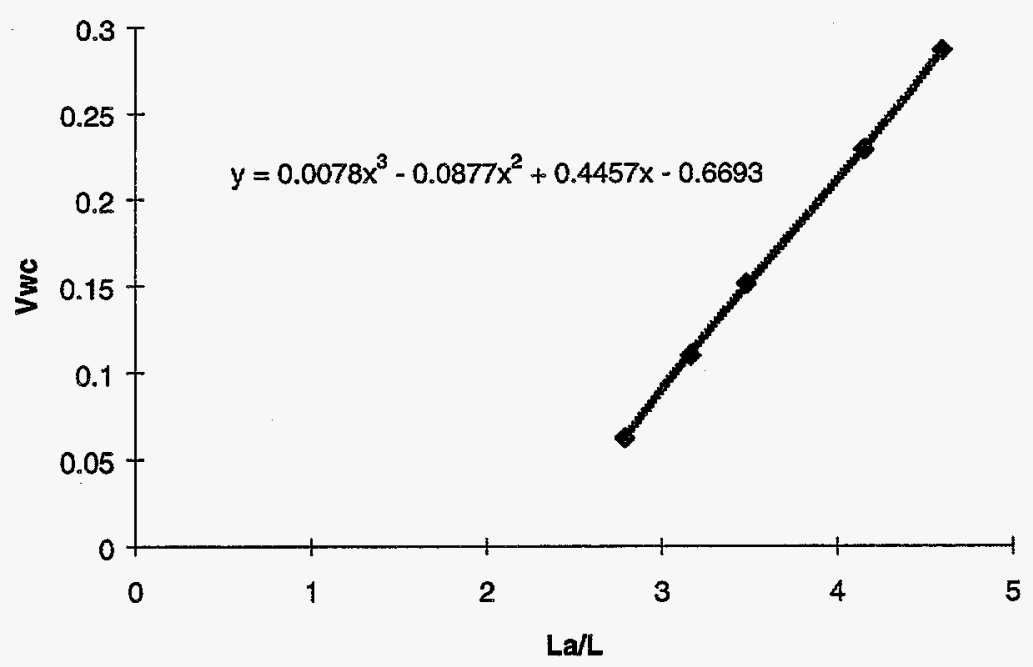

Figure A-3

$6 \%$ Bentonite, Phase I, $120^{\prime}$ Cable

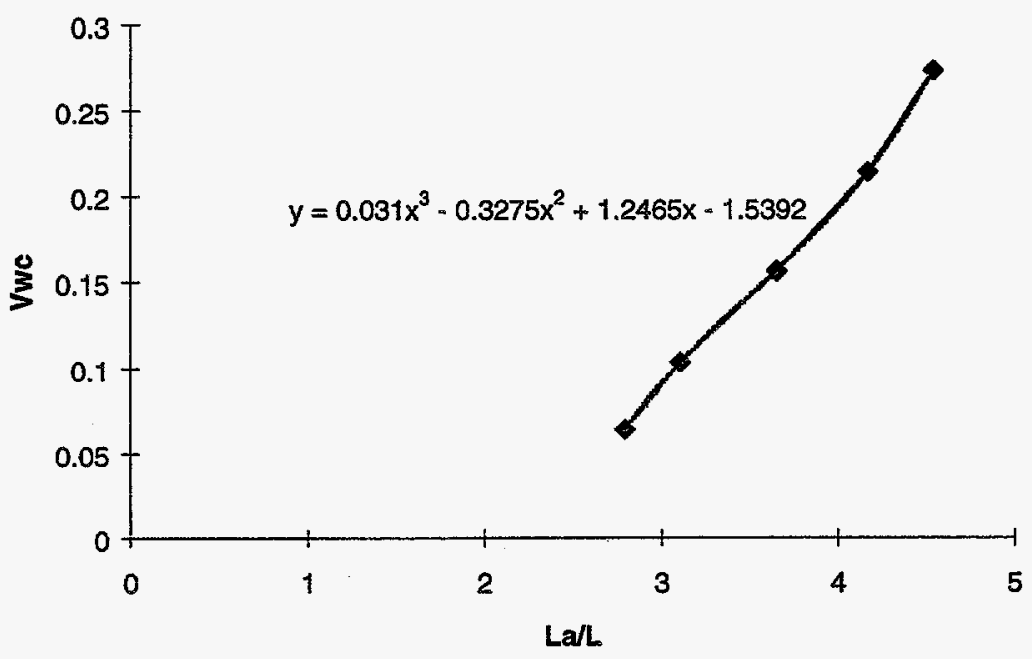

Figure A-4 
Intentionally Left Blank 
6\% Bentonite, Phase I, 138' Cable

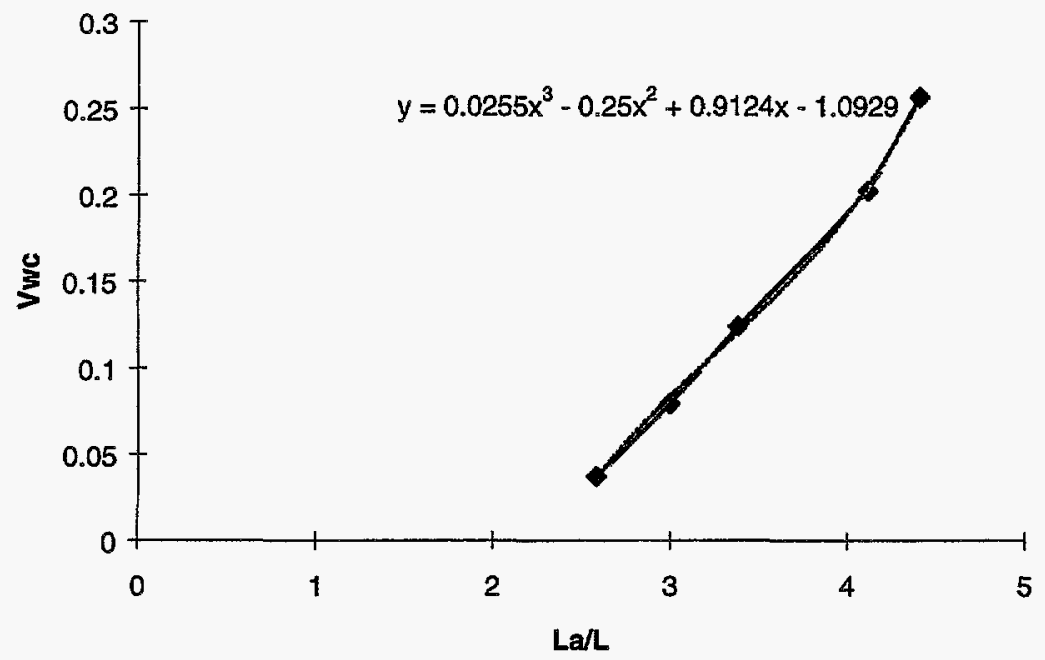

Figure A-5

Compacted Native Soll, Phase I, 59' Cable

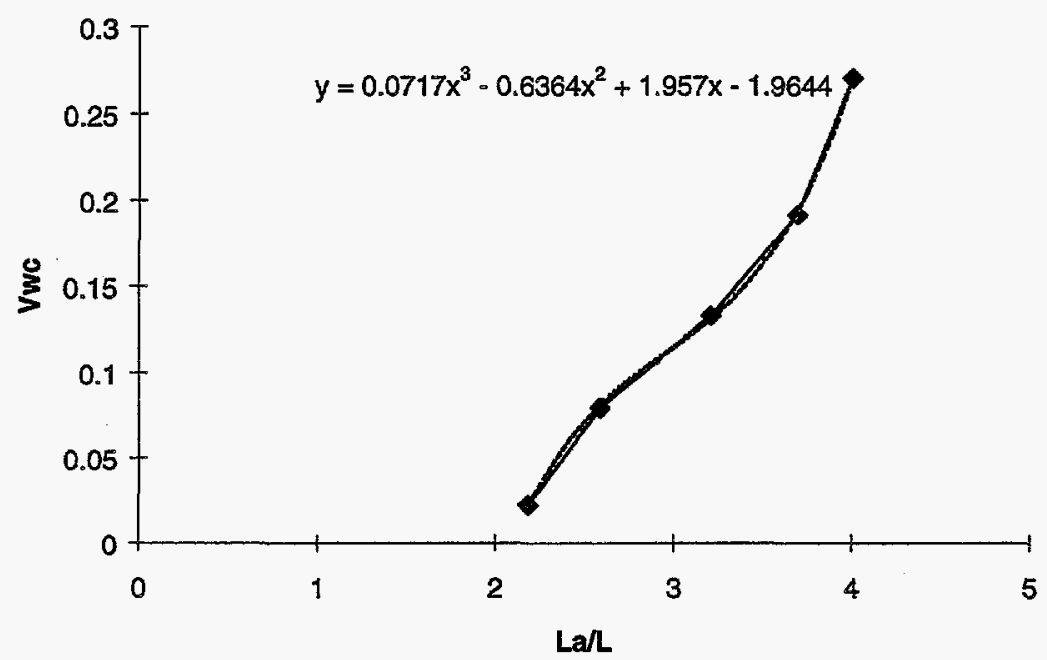

Figure A-6 
Intentionally Left Blank 
Compacted Native Soll, Phase 1, 82' Cable

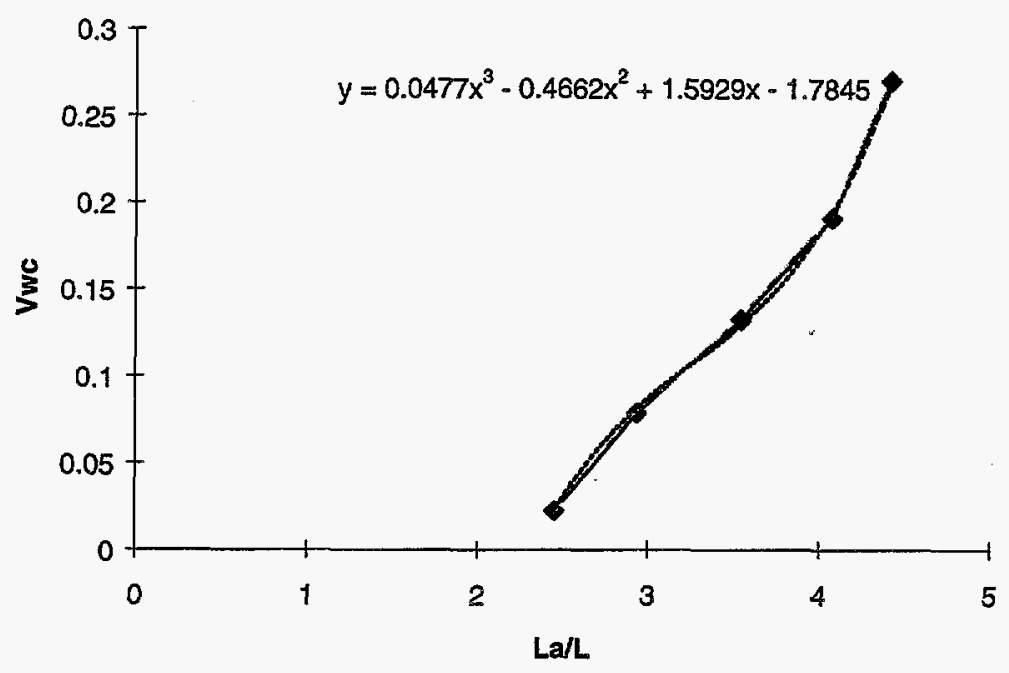

Figure A-7

Compacted Native Soil, Phase I, 98' Cable

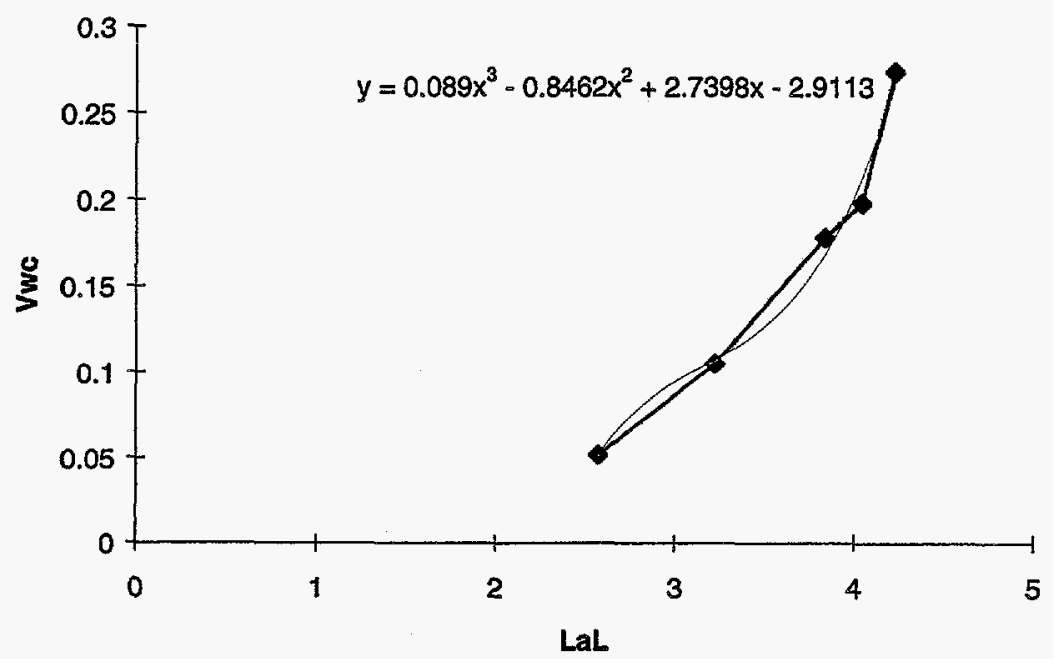

Figure A-8 
Intentionally Left Blank

A- 10 
Compacted Native Soil, Phase I, 120' Cable

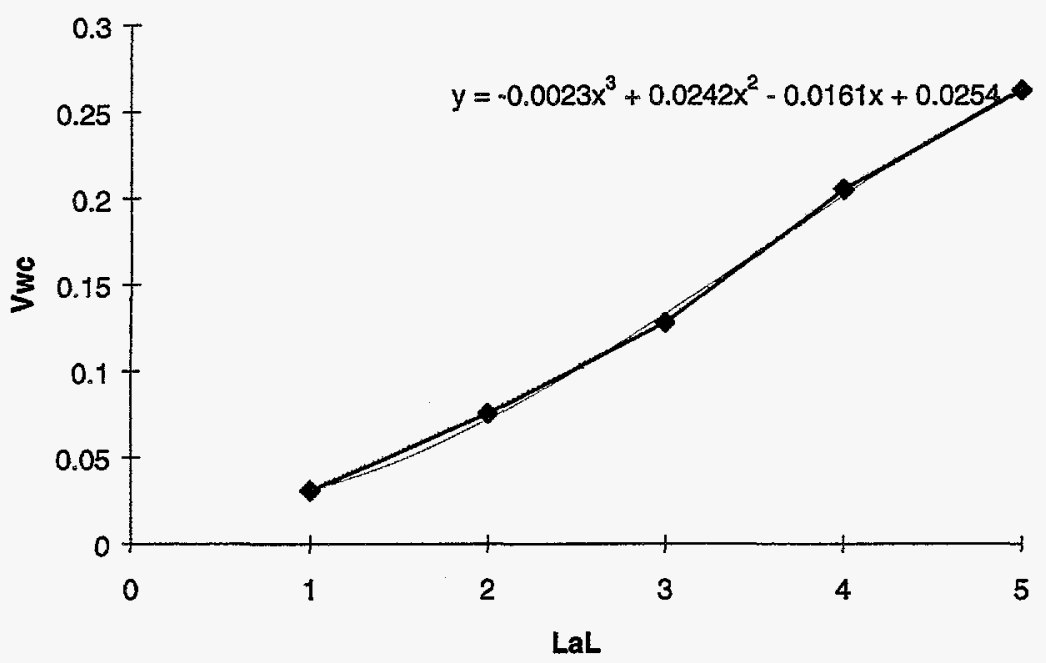

Figure A-9

Compacted Native Soil, Phase I, 138' Cable

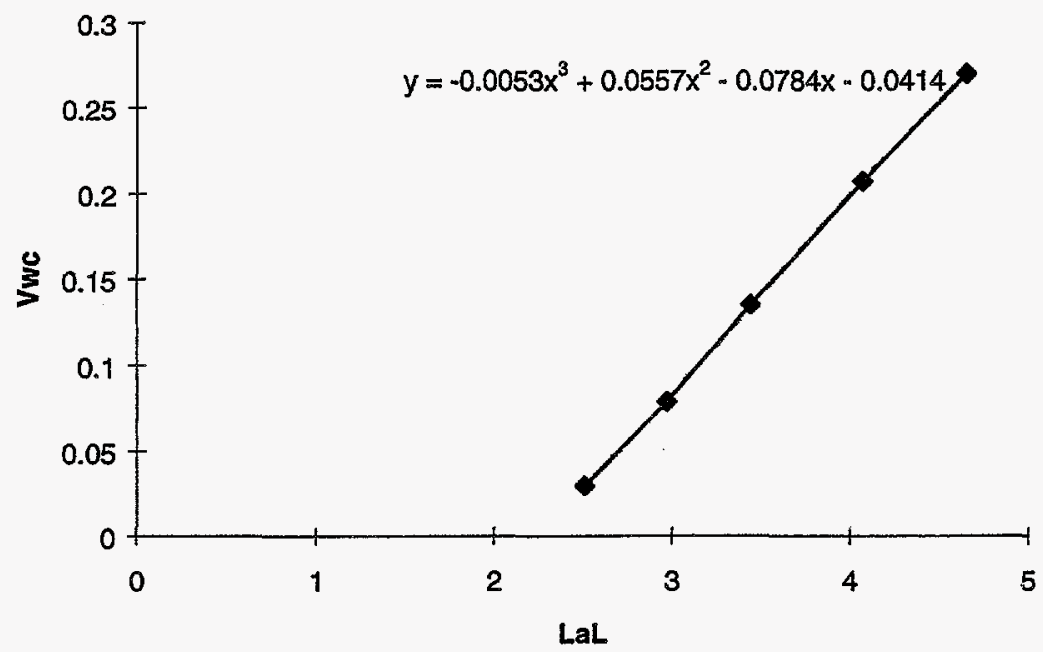

Figure A-10 
Intentionally Left Blank 


\section{Uncompacted Native Soil, Phase I, 59' Cable}

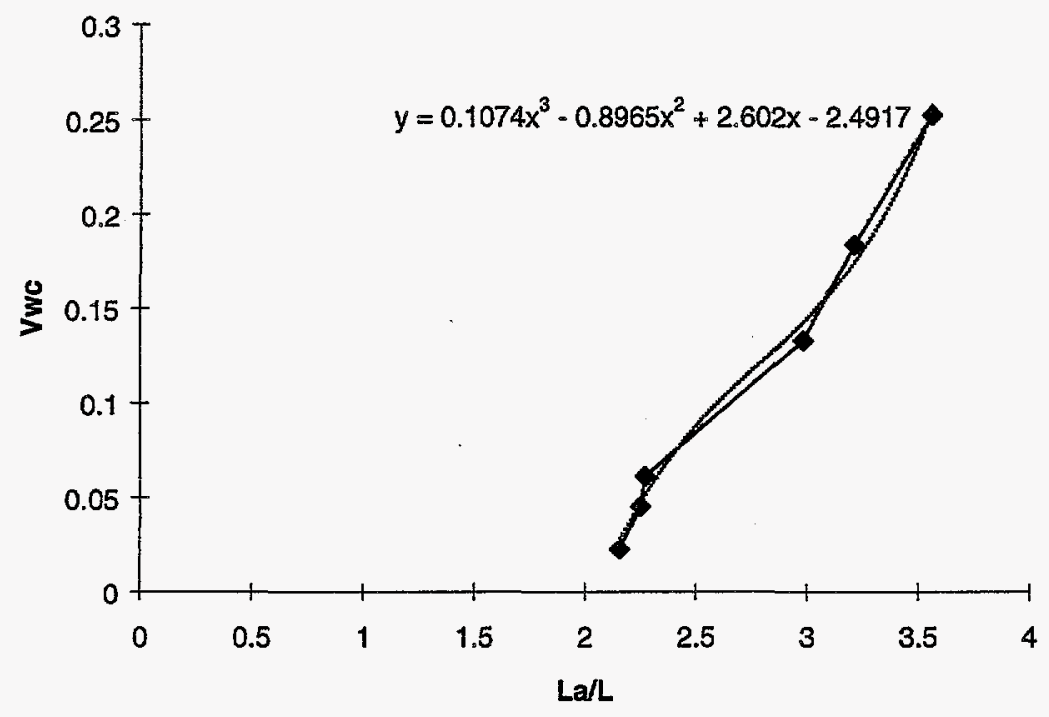

Figure A-11

\section{Uncompacted Native Soil, Phase 1, $82^{\prime}$ Cable}

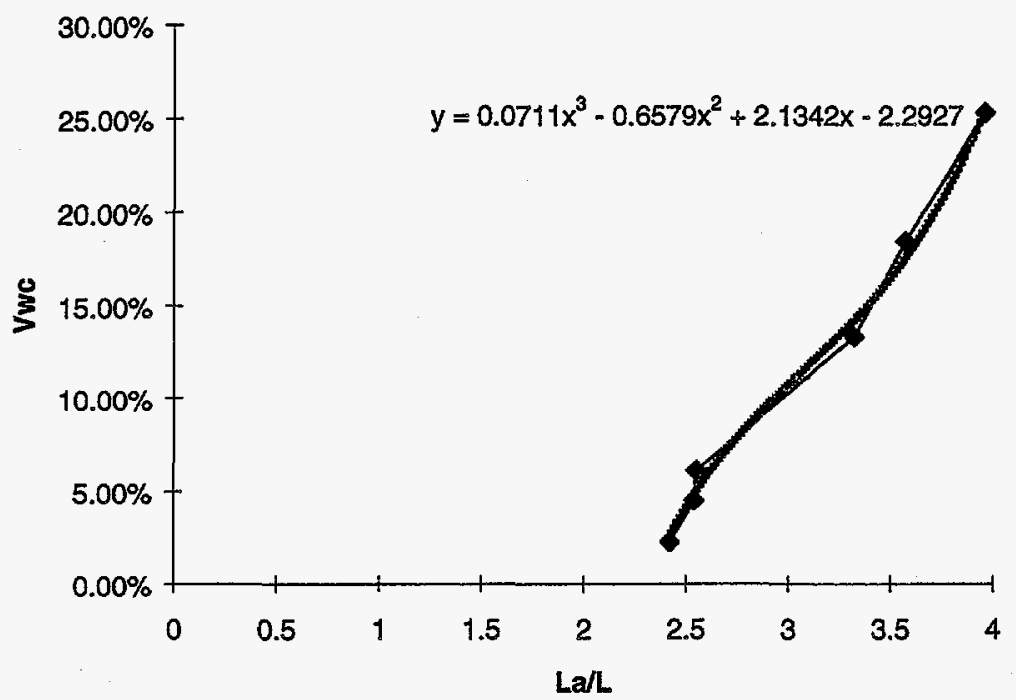

Figure A-12 
Intentionally Left Blank

A-14 


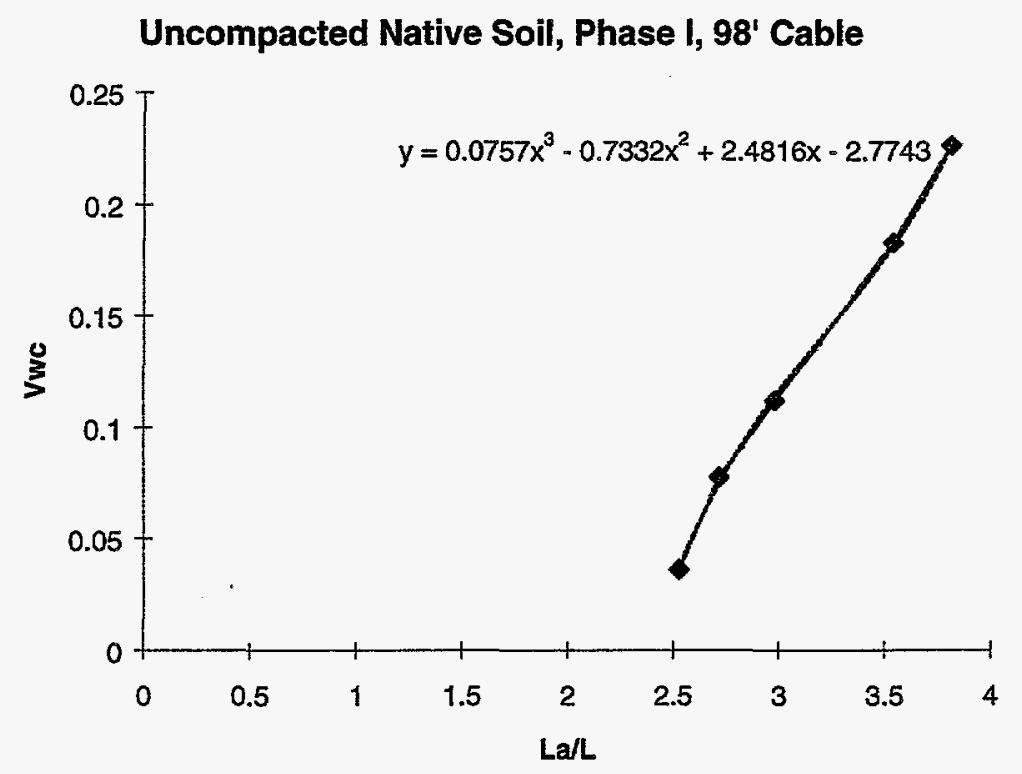

Figure A-13

\section{Uncompacted Native Soil, Phase I, 120' Cable}

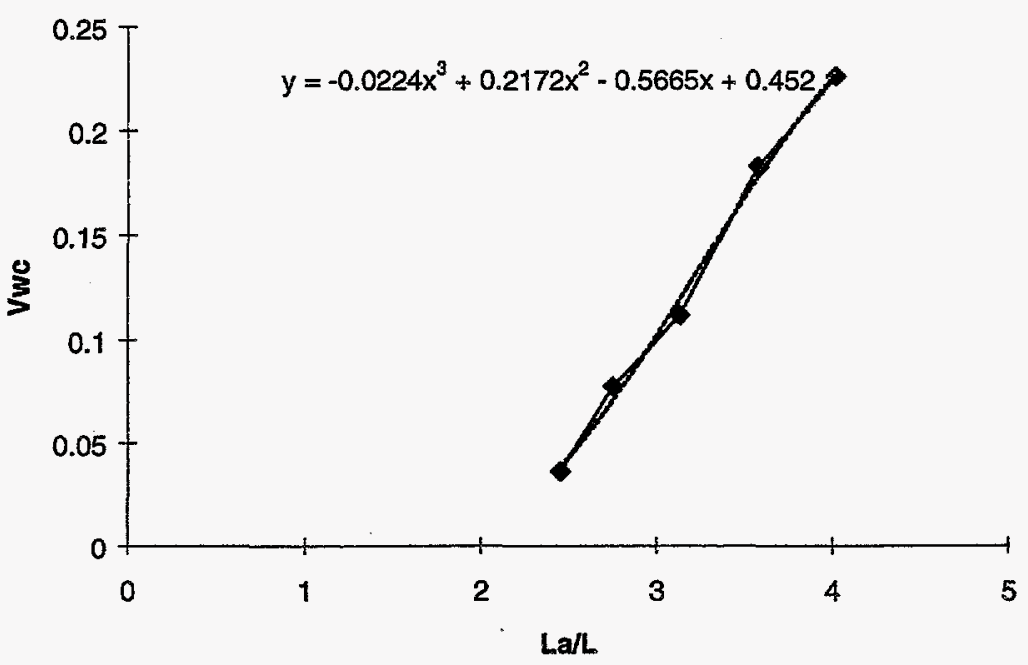

Figure A-14 
Intentionally Left Blank

A-16 
Uncompacted Native Soil, Phase I, 138' Cable

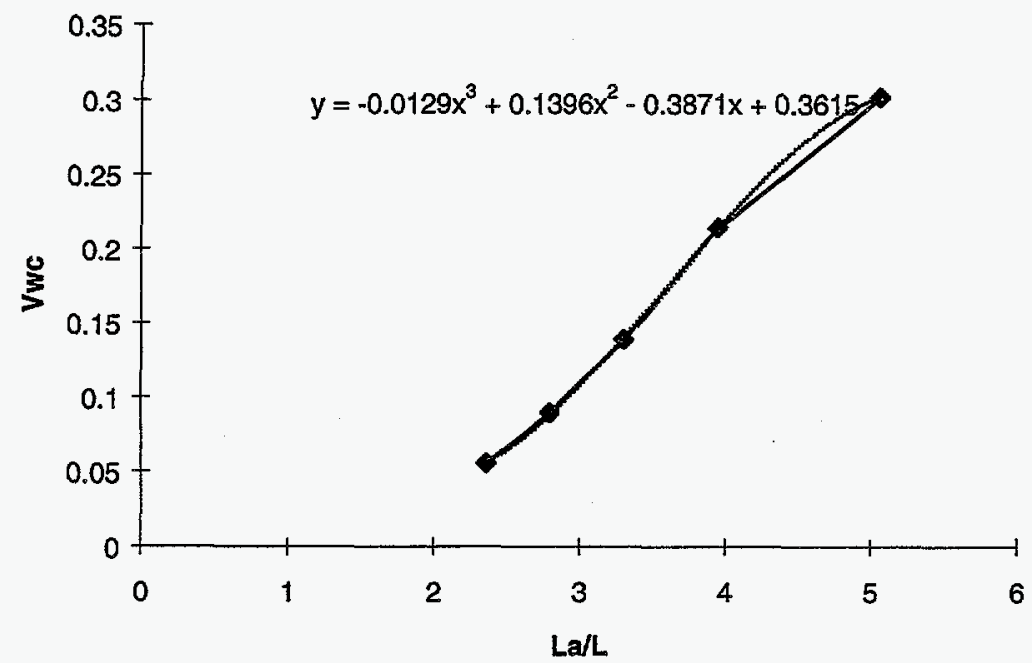

Figure A-15

Sand, Phase I, Short Cables

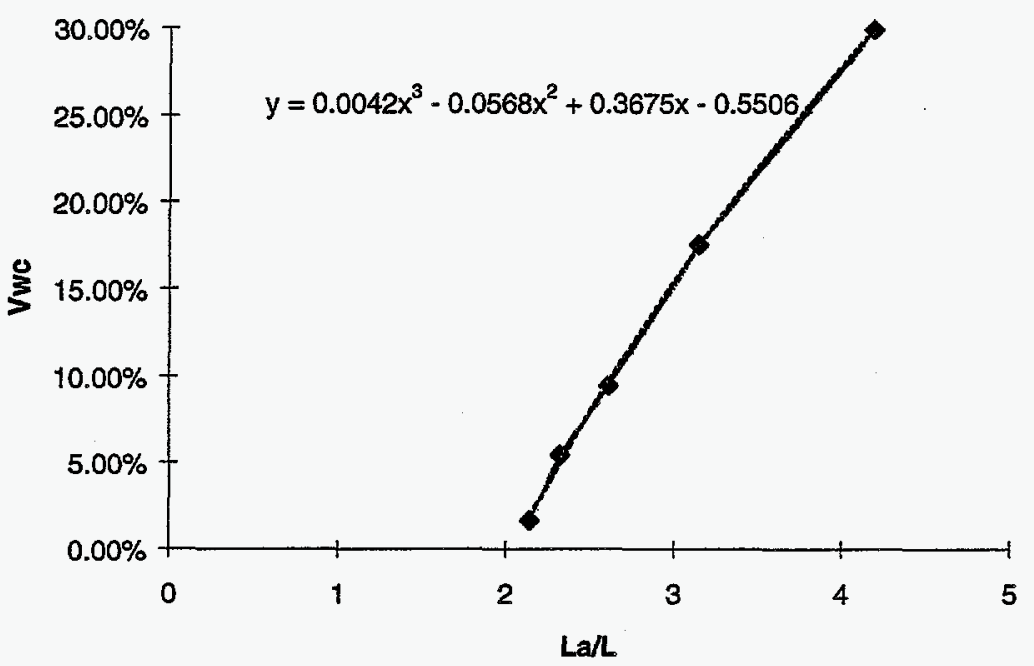

Figure A-16 
Intentionally Left Blank

A-18 
Sand, Phase I, Long Cables

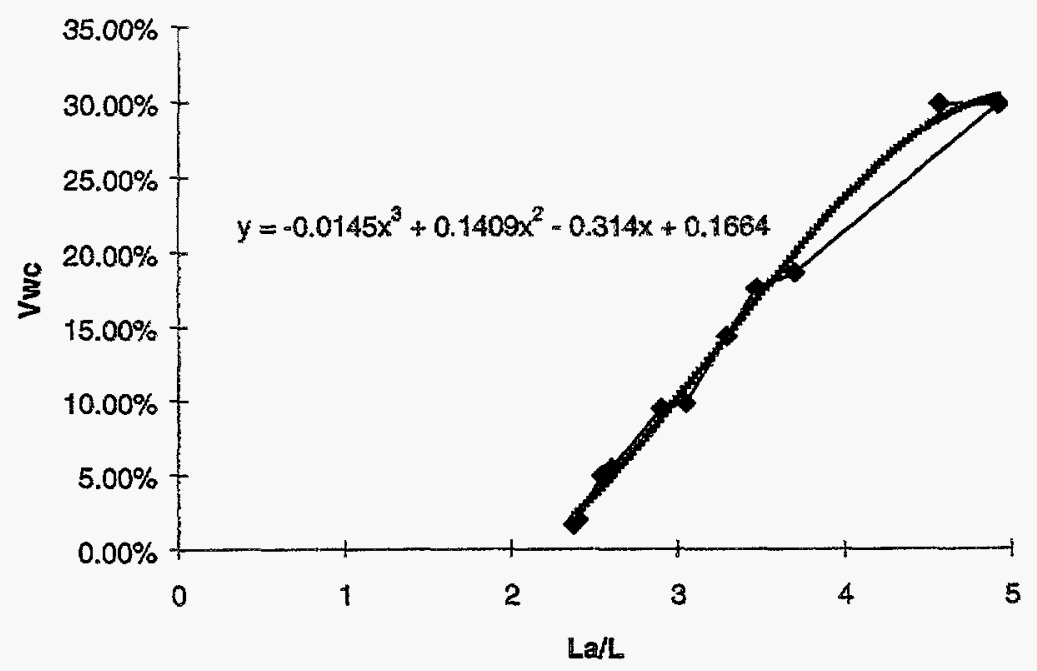

Figure A-17

Compacted Native Soil, Phase II, 85' Cable

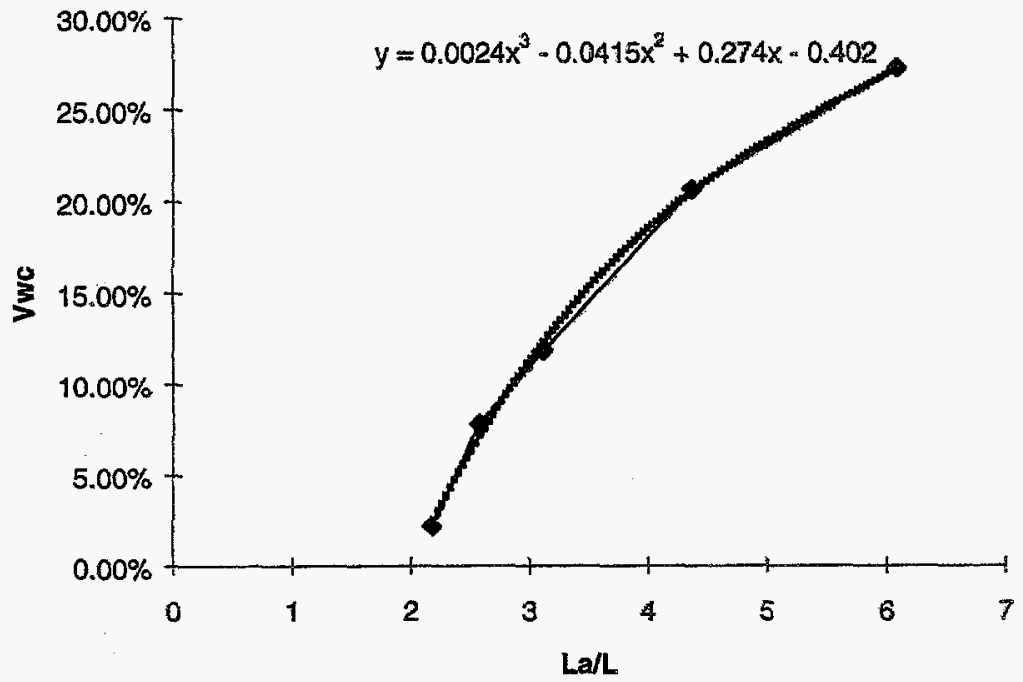

Figure A-18 


\section{Intentionally Left Blank}




\section{Compacted Native Soil, Phase II, 102' Cable}

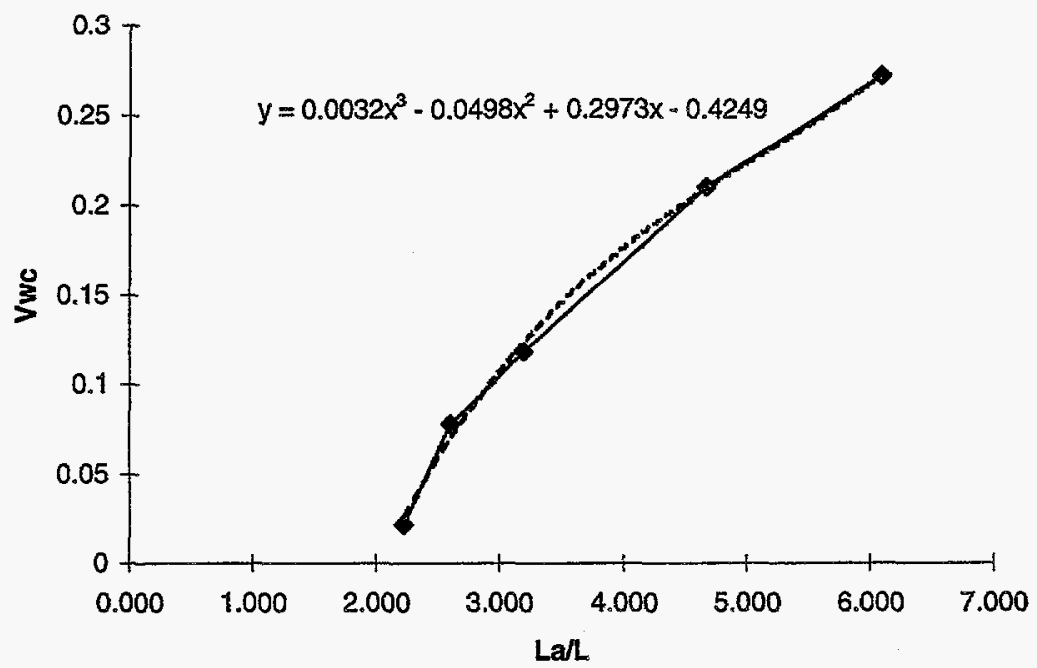

Figure A-19

Compacted Native Soil, Phase II, 119' Cable

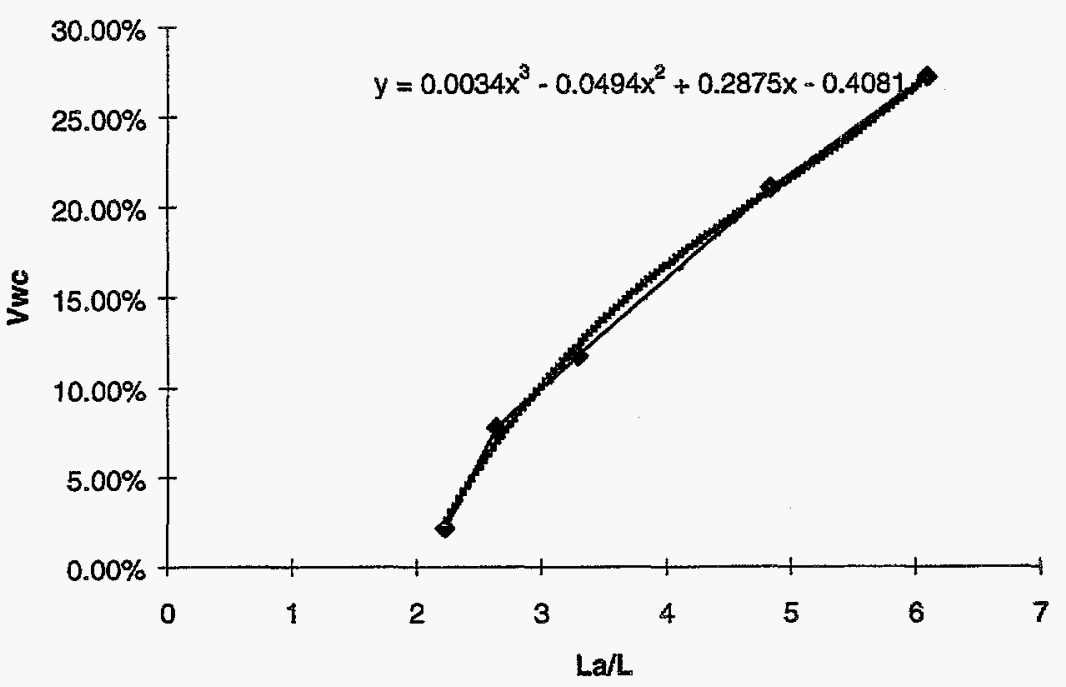

Figure A-20 
Intentionally Left Blank 


\section{Compacted Native Soil, Phase II, 138' Cable}

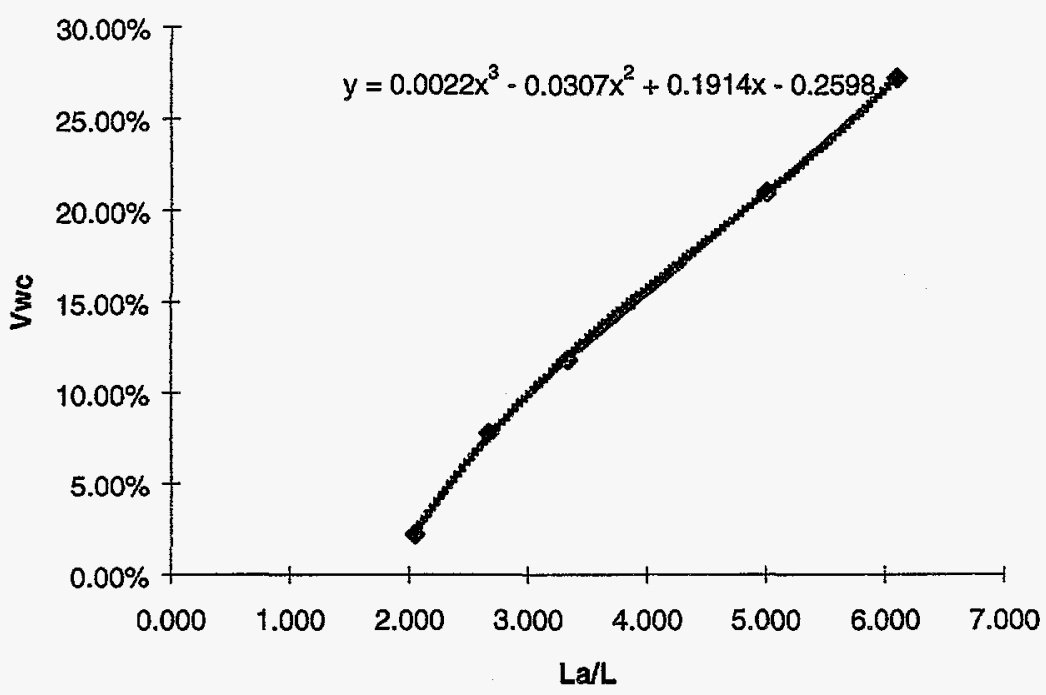

Figure A-21

Compacted Native Soil, Phase $\mathrm{II}_{5}$ 156' Cable

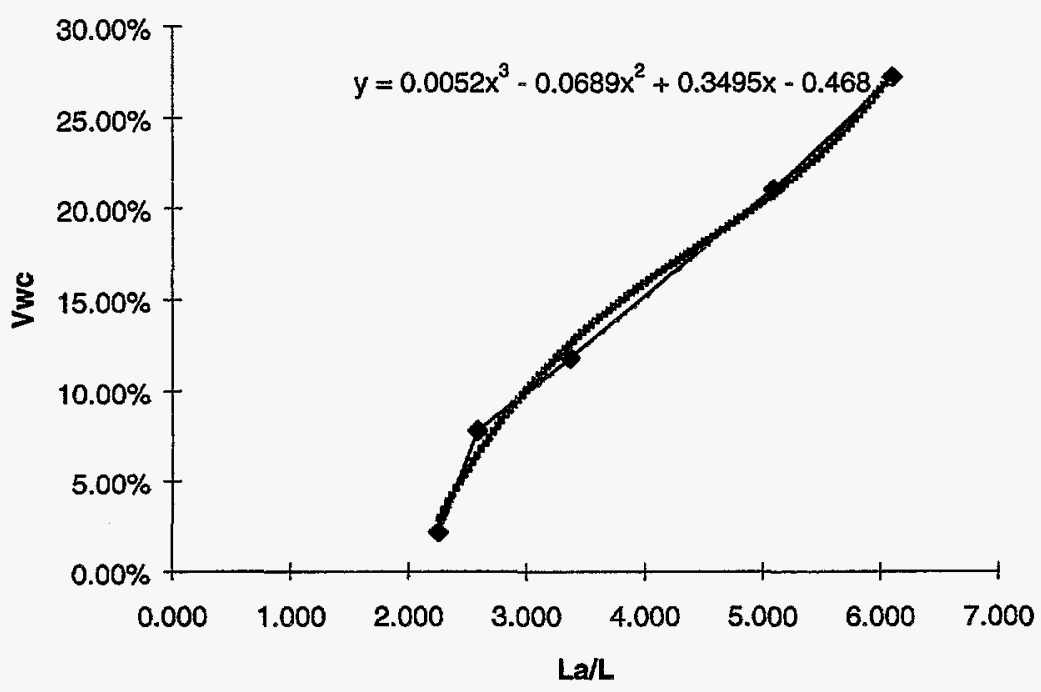

Figure A-22 
Intentionally Left Blank

A-24 
Uncompacted Native Soil, Phase II, 85' Cable

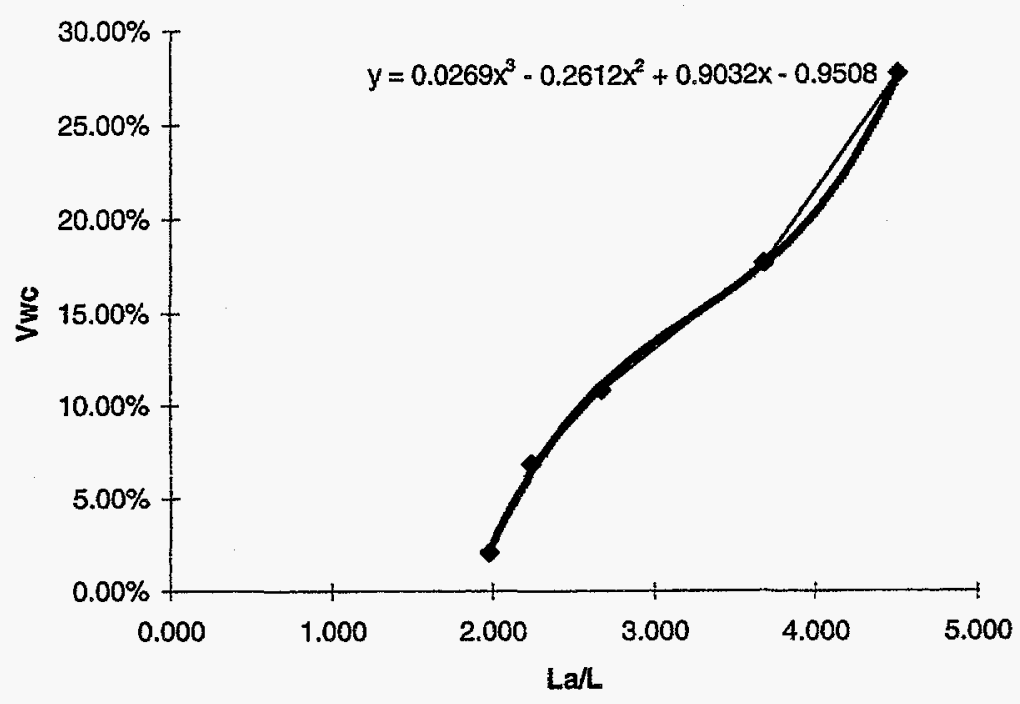

Figure A-23

\section{Uncompacted Native Soil, Phase II, 102' Cable}

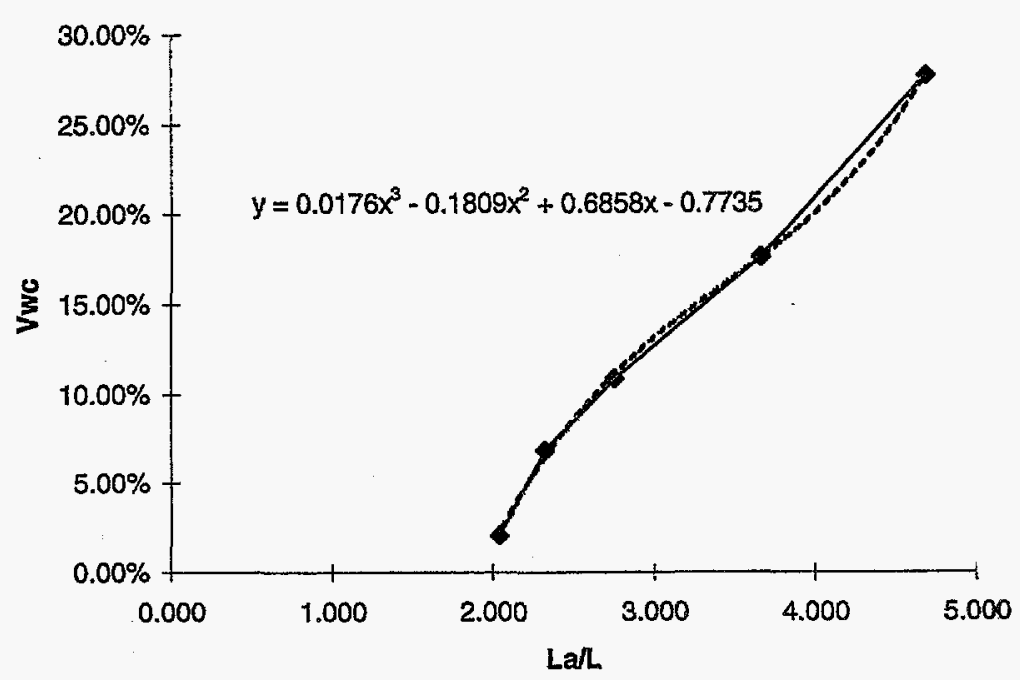

Figure A-24 
Intentionally Left Blank 
Uncompacted Native Soil, Phase II, 119' Cable

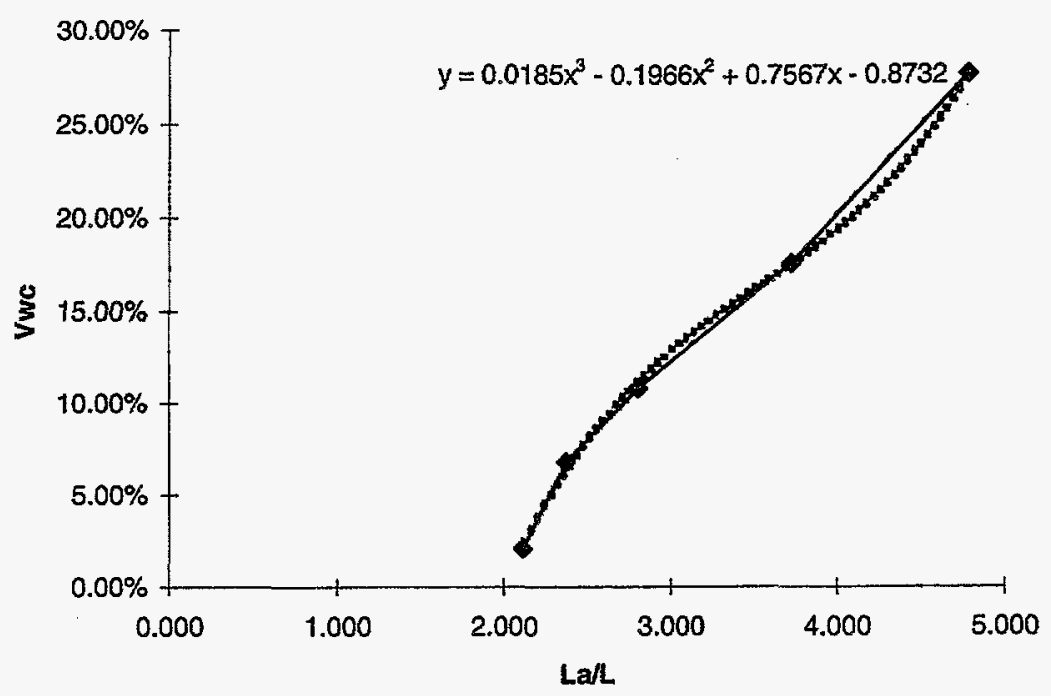

Figure A-25

Uncompacted Native Soil, Phase Il, 138' Cable

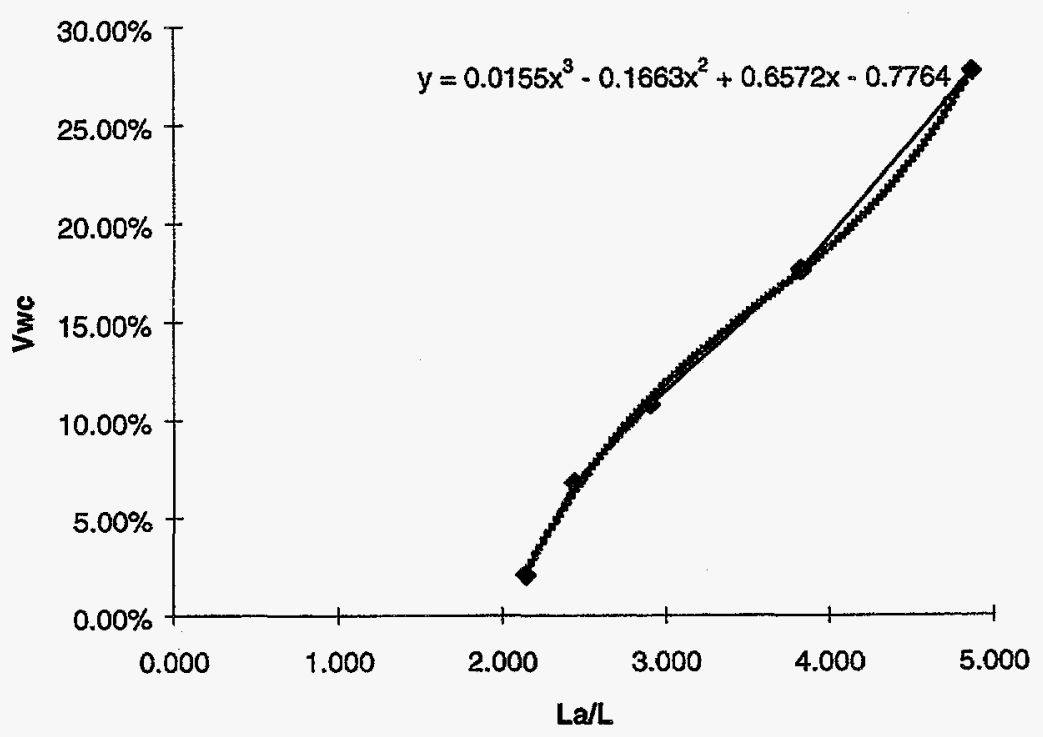

Figure A-26 
Intentionally Left Blank 
Uncompacted Native Soil, Phase II, 156' Cable

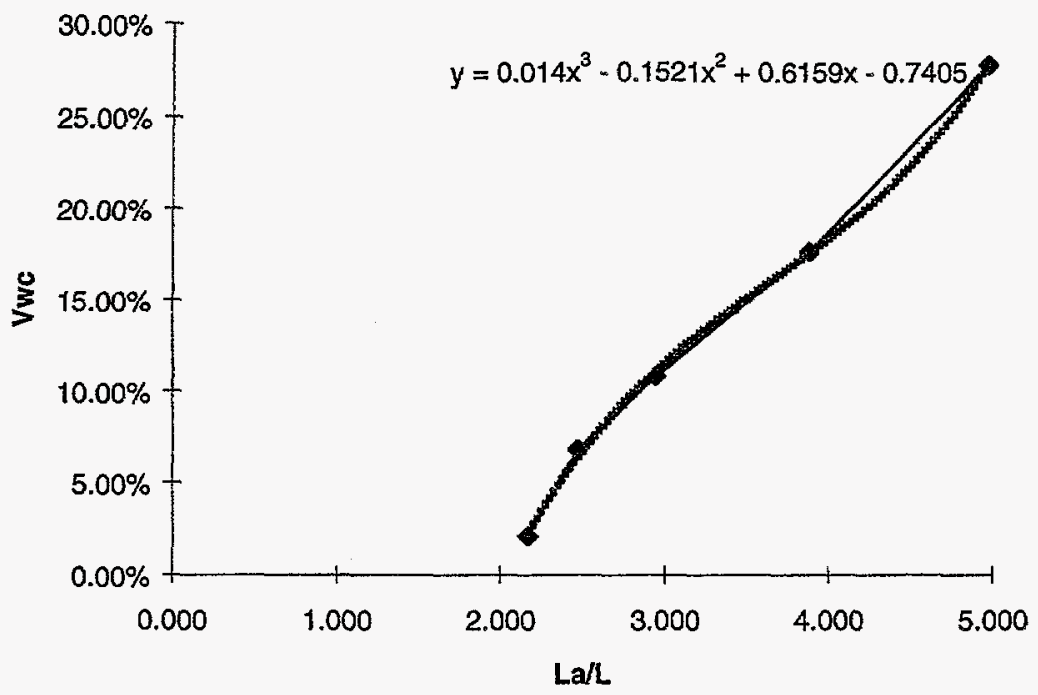

Figure A-27

Sand, Phase II, All Cable Lengths

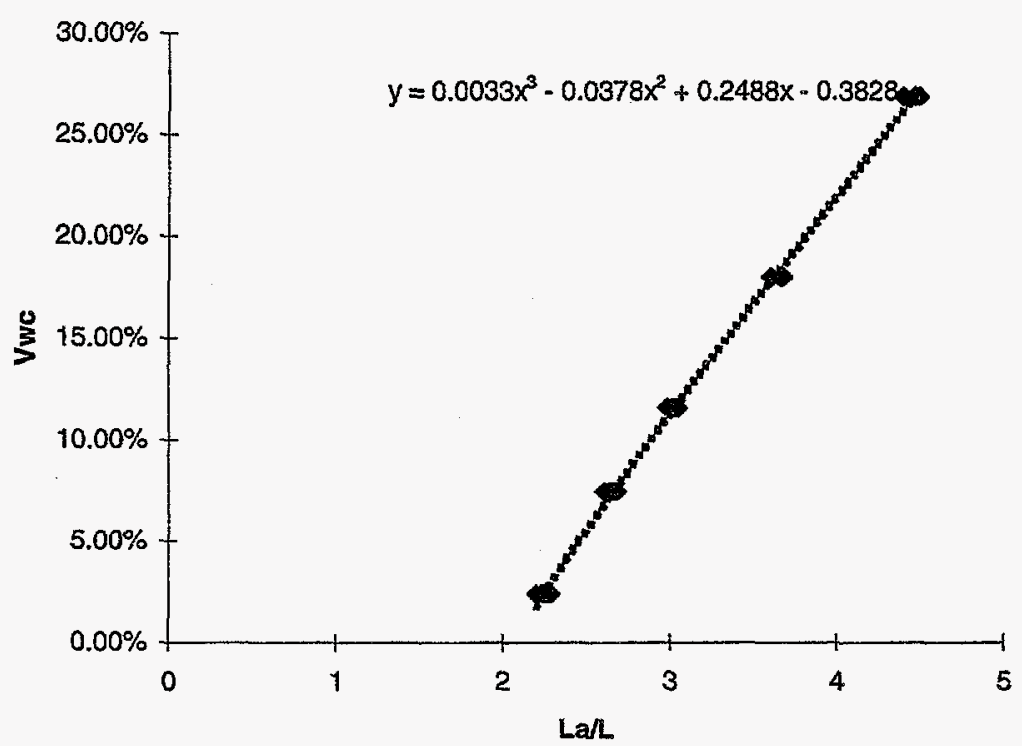

Figure A-28 
Intentionally Left Blank 


\section{Appendix B}

Volumetric Moisture Content Calculations 
Intentionally Left Blank 
Table B1: Moisture Content for Phase 1 Probe, 138' Cable, 6\% Bentonite

\begin{tabular}{|c|c|c|c|c|c|c|}
\hline M of Wet Soil & M of Solids & $\begin{array}{c}\text { Moisture } \\
\text { Content }(\mathrm{w})\end{array}$ & $\begin{array}{c}\text { Total Mass } \\
(\mathrm{lbs})\end{array}$ & Total Mass (g) & V of Water & Volumetric w \\
\hline 125.2 & 122.4 & $2.29 \%$ & 15.25 & 6713.24 & 150.14 & $3.70 \%$ \\
\hline 209 & 199 & $5.03 \%$ & 15.3 & 6735.92 & 322.29 & $7.94 \%$ \\
\hline 125.1 & 116.6 & $7.29 \%$ & 16.81 & 7420.85 & 504.21 & $12.42 \%$ \\
\hline 80 & 71.9 & $11.27 \%$ & 18.35 & 8119.39 & 822.09 & $20.26 \%$ \\
\hline 198.3 & 173.5 & $14.29 \%$ & 18.8 & 8323.51 & 1040.96 & $25.65 \%$ \\
\hline
\end{tabular}

Table B2: Moisture Content for Phase 1 Probe, 59' Cable, 6\% Bentonite

\begin{tabular}{|c|c|c|c|c|c|c|}
\hline M of Wet Soil & M of Solids & $\begin{array}{c}\text { Moisture } \\
\text { Content (w) }\end{array}$ & $\begin{array}{c}\text { Total Mass } \\
(\mathrm{lbs})\end{array}$ & Total Mass (g) & V of Water & Volumetric w \\
\hline 157.4 & 150.8 & $4.38 \%$ & 15.08 & 6636.124467 & 278.26 & $6.86 \%$ \\
\hline 95.4 & 89 & $7.19 \%$ & 16.38 & 7225.800599 & 484.75 & $11.94 \%$ \\
\hline 155.2 & 140.8 & $10.23 \%$ & 16.88 & 7452.599111 & 691.48 & $17.04 \%$ \\
\hline 126.5 & 110.7 & $14.27 \%$ & 17.94 & 7933.411957 & 990.89 & $24.42 \%$ \\
\hline 209.4 & 179.3 & $16.79 \%$ & 18.59 & 8228.250023 & 1182.76 & $29.14 \%$ \\
\hline
\end{tabular}

Table B3: Moisture Content for Phase 1 Probe, 82' Cable, 6\% Bentonite

\begin{tabular}{|c|c|c|c|c|c|c|}
\hline M of Wet Soil & M of Solids & $\begin{array}{c}\text { Moisture } \\
\text { Content }(\mathrm{w})\end{array}$ & $\begin{array}{c}\text { Total Mass } \\
(\mathrm{lbs})\end{array}$ & Total Mass (g) & V of Water & Volumetric w \\
\hline 157.4 & 150.8 & $4.38 \%$ & 15.08 & 6636.12 & 278.26 & $6.86 \%$ \\
\hline 95.4 & 89 & $7.19 \%$ & 16.38 & 7225.80 & 484.75 & $11.94 \%$ \\
\hline 155.2 & 140.8 & $10.23 \%$ & 16.88 & 7452.60 & 691.48 & $17.04 \%$ \\
\hline 126.5 & 110.7 & $14.27 \%$ & 17.94 & 7933.41 & 990.89 & $24.42 \%$ \\
\hline 209.4 & 179.3 & $16.79 \%$ & 18.59 & 8228.25 & 1182.76 & $29.14 \%$ \\
\hline
\end{tabular}

Table B4: Moisture Content for Phase 1 Probe, 98' Cable, 6\% Bentonite

\begin{tabular}{|c|c|c|c|c|c|c|}
\hline M of Wet Soil & M of Solids & $\begin{array}{c}\text { Moisture } \\
\text { Content (w) }\end{array}$ & $\begin{array}{c}\text { Total Mass } \\
(\mathrm{lbs})\end{array}$ & Total Mass (g) & V of Water & Volumetric w \\
\hline 197.7 & 190.4 & $3.83 \%$ & 15.52 & 6835.71 & 252.41 & $6.22 \%$ \\
\hline 92.7 & 86.9 & $6.67 \%$ & 16.15 & 7121.47 & 445.57 & $10.98 \%$ \\
\hline 122.9 & 112.8 & $8.95 \%$ & 16.93 & 7475.28 & 614.32 & $15.14 \%$ \\
\hline 132.6 & 116.9 & $13.43 \%$ & 17.75 & 7847.23 & 929.12 & $22.89 \%$ \\
\hline 189.8 & 163.6 & $16.01 \%$ & 19.01 & 8418.76 & 1162.13 & $28.64 \%$ \\
\hline
\end{tabular}


Table B5: Moisture Content for Phase 1 Probe, 120' Cable, 6\% Bentonite

\begin{tabular}{|c|c|c|c|c|c|c|}
\hline M of Wet Soil & M of Solids & $\begin{array}{c}\text { Moisture } \\
\text { Content }(\mathrm{w})\end{array}$ & $\begin{array}{c}\text { Total Mass } \\
(\mathrm{bs})\end{array}$ & Total Mass $(\mathrm{g})$ & V of Water & Volumetric w \\
\hline 127.4 & 122.6 & $3.92 \%$ & 15.61 & 6876.53 & 259.08 & $6.38 \%$ \\
\hline 108.6 & 102 & $6.47 \%$ & 15.65 & 6894.67 & 419.01 & $10.32 \%$ \\
\hline 107.4 & 98 & $9.59 \%$ & 16.4 & 7234.87 & 633.22 & $15.60 \%$ \\
\hline 125 & 110.8 & $12.82 \%$ & 17.29 & 7638.57 & 867.74 & $21.38 \%$ \\
\hline 191.4 & 164.9 & $16.07 \%$ & 18.1 & 8005.99 & 1108.46 & $27.31 \%$ \\
\hline
\end{tabular}

Table B6: Moisture Content for Phase 1 Probe, 59' Cable, Compacted Native Soil

\begin{tabular}{|c|c|c|c|c|c|c|}
\hline M of Wet Soil & M of Solids & $\begin{array}{c}\text { Moisture } \\
\text { Content (w) }\end{array}$ & $\begin{array}{c}\text { Total Mass } \\
(\mathrm{lbs})\end{array}$ & Total Mass (g) & V of Water & Volumetric w \\
\hline 145.7 & 143.7 & $1.39 \%$ & 14.5 & 6577.16 & 90.28 & $2.22 \%$ \\
\hline 70.7 & 67.4 & $4.90 \%$ & 15.6 & 6871.99 & 320.76 & $7.90 \%$ \\
\hline 110.1 & 102.3 & $7.62 \%$ & 17.22 & 7606.82 & 538.90 & $13.28 \%$ \\
\hline 117.4 & 106.3 & $10.44 \%$ & 18.56 & 8214.64 & 776.68 & $19.14 \%$ \\
\hline 231.6 & 200.2 & $15.68 \%$ & 18.3 & 8096.71 & 1097.74 & $27.05 \%$ \\
\hline
\end{tabular}

Table B7: Moisture Content for Phase 1 Probe, 82' Cable, Compacted Native Soil

\begin{tabular}{|c|c|c|c|c|c|c|}
\hline M of Wet Soil & M of Solids & $\begin{array}{c}\text { Moisture } \\
\text { Content (w) }\end{array}$ & $\begin{array}{c}\text { Total Mass } \\
\text { (lbs) }\end{array}$ & Total Mass (g) & V of Water & Volumetric w \\
\hline 145.7 & 143.7 & $1.39 \%$ & 14.5 & 6577.16 & 90.28 & $2.22 \%$ \\
\hline 70.7 & 67.4 & $4.90 \%$ & 15.6 & 6871.99 & 320.76 & $7.90 \%$ \\
\hline 110.1 & 102.3 & $7.62 \%$ & 17.22 & 7606.82 & 538.90 & $13.28 \%$ \\
\hline 117.4 & 106.3 & $10.44 \%$ & 18.56 & 8214.64 & 776.68 & $19.14 \%$ \\
\hline 231.6 & 200.2 & $15.68 \%$ & 18.3 & 8096.71 & 1097.74 & $27.05 \%$ \\
\hline
\end{tabular}

Table B8: Moisture Content for Phase 1 Probe, 98' Cable, Compacted Native Soil

\begin{tabular}{|c|c|c|c|c|c|c|}
\hline M of Wet Soil & M of Solids & $\begin{array}{c}\text { Moisture } \\
\text { Content (w) }\end{array}$ & $\begin{array}{c}\text { Total Mass } \\
(\mathrm{lbs})\end{array}$ & Total Mass (g) & V of Water & Volumetric w \\
\hline 139.5 & 135 & $3.33 \%$ & 14.31 & 6490.97 & 209.39 & $5.16 \%$ \\
\hline 95 & 89.2 & $6.50 \%$ & 15.85 & 6985.39 & 426.48 & $10.51 \%$ \\
\hline 126.9 & 115.2 & $10.16 \%$ & 17.74 & 7842.69 & 723.09 & $17.82 \%$ \\
\hline 212.8 & 191.8 & $10.95 \%$ & 18.43 & 8155.67 & 804.84 & $19.83 \%$ \\
\hline 170 & 146.6 & $15.96 \%$ & 18.27 & 8083.10 & 1112.61 & $27.42 \%$ \\
\hline
\end{tabular}


Table B9: Moisture Content for Phase 1 Probe, 120' Cable, Compacted Native Soil

\begin{tabular}{|c|c|c|c|c|c|c|}
\hline M of Wet Soil & M of Solids & $\begin{array}{c}\text { Moisture } \\
\text { Content (w) }\end{array}$ & $\begin{array}{c}\text { Total Mass } \\
(\mathrm{bs})\end{array}$ & Total Mass (g) & V of Water & Volumetric w \\
\hline 160.7 & 157.7 & $1.90 \%$ & 14.6 & 6622.52 & 123.63 & $3.05 \%$ \\
\hline 86 & 82 & $4.88 \%$ & 14.93 & 6568.08 & 305.49 & $7.53 \%$ \\
\hline 130.1 & 120.9 & $7.61 \%$ & 16.68 & 7361.88 & 520.59 & $12.83 \%$ \\
\hline 152.2 & 136.5 & $11.50 \%$ & 18.26 & 8078.56 & 833.33 & $20.53 \%$ \\
\hline 217.5 & 188.6 & $15.32 \%$ & 18.16 & 8033.20 & 1067.40 & $26.30 \%$ \\
\hline
\end{tabular}

Table B10: Moisture Content for Phase 1 Probe, 138' Cable, Compacted Native Soil

\begin{tabular}{|c|c|c|c|c|c|c|}
\hline M of Wet Soil & M of Solids & $\begin{array}{c}\text { Moisture } \\
\text { Content (w) }\end{array}$ & $\begin{array}{c}\text { Total Mass } \\
(\mathrm{bs})\end{array}$ & Total Mass (g) & V of Water & Volumetric w \\
\hline 189.2 & 185.8 & $1.83 \%$ & 14.66 & 6649.73 & 119.50 & $2.94 \%$ \\
\hline 84.5 & 80.4 & $5.10 \%$ & 14.99 & 6595.30 & 320.01 & $7.89 \%$ \\
\hline 143.7 & 133 & $8.05 \%$ & 16.66 & 7352.81 & 547.50 & $13.49 \%$ \\
\hline 149.8 & 134.3 & $11.54 \%$ & 18.34 & 8114.85 & 839.65 & $20.69 \%$ \\
\hline 213.8 & 185.2 & $15.44 \%$ & 18.49 & 8182.89 & 1094.62 & $26.97 \%$ \\
\hline
\end{tabular}

Table B11: Moisture Content for Phase 1 Probe, 59' Cable, Sand

\begin{tabular}{|c|c|c|c|c|c|c|}
\hline M of Wet Soil & M of Solids & $\begin{array}{c}\text { Moisture } \\
\text { Content }(\mathrm{w})\end{array}$ & $\begin{array}{c}\text { Total Mass } \\
(\mathrm{bss})\end{array}$ & Total Mass (g) & V of Water & Volumetric w \\
\hline 183.7 & 181.9 & $0.99 \%$ & 15.28 & 6726.84 & 65.91 & $1.62 \%$ \\
\hline 204.5 & 197.7 & $3.44 \%$ & 15 & 6599.84 & 219.46 & $5.41 \%$ \\
\hline 194.8 & 183.3 & $6.27 \%$ & 14.73 & 6477.37 & 382.39 & $9.42 \%$ \\
\hline 271.7 & 244.3 & $11.22 \%$ & 15.99 & 7048.90 & 710.86 & $17.52 \%$ \\
\hline 297.8 & 249.9 & $19.17 \%$ & 17.09 & 7547.85 & 1214.04 & $29.91 \%$ \\
\hline
\end{tabular}

Table B12: Moisture Content for Phase 1 Probe, $82^{\prime}$ Cable, Sand

\begin{tabular}{|c|c|c|c|c|c|c|}
\hline M of Wet Soil & M of Solids & $\begin{array}{c}\text { Moisture } \\
\text { Content }(\mathrm{w})\end{array}$ & $\begin{array}{c}\text { Total Mass } \\
(\mathrm{lbs})\end{array}$ & Total Mass (g) & V of Water & Volumetric w \\
\hline 183.7 & 181.9 & $0.99 \%$ & 15.28 & 6726.84 & 65.91 & $1.62 \%$ \\
\hline 204.5 & 197.7 & $3.44 \%$ & 15 & 6599.84 & 219.46 & $5.41 \%$ \\
\hline 194.8 & 183.3 & $6.27 \%$ & 14.73 & 6477.37 & 382.39 & $9.42 \%$ \\
\hline 271.7 & 244.3 & $11.22 \%$ & 15.99 & 7048.90 & 710.86 & $17.52 \%$ \\
\hline 297.8 & 249.9 & $19.17 \%$ & 17.09 & 7547.85 & 1214.04 & $29.91 \%$ \\
\hline
\end{tabular}


Table B13: Moisture Content for Phase 1 Probe, 138' Cable, Sand

\begin{tabular}{|c|c|c|c|c|c|c|}
\hline M of Wet Soil & M of Solids & $\begin{array}{c}\text { Moisture } \\
\text { Content (w) }\end{array}$ & $\begin{array}{c}\text { Total Mass } \\
(\mathrm{lbs})\end{array}$ & Total Mass (g) & V of Water & Volumetric w \\
\hline 161.8 & 159.9 & $1.19 \%$ & 15.47 & 6813.03 & 80.00 & $1.97 \%$ \\
\hline 141.1 & 136.7 & $3.22 \%$ & 14.5 & 6373.04 & 198.73 & $4.90 \%$ \\
\hline 223.1 & 209.9 & $6.29 \%$ & 15.33 & 6749.52 & 399.34 & $9.84 \%$ \\
\hline 192.4 & 175.8 & $9.44 \%$ & 15.35 & 6758.60 & 583.12 & $14.37 \%$ \\
\hline 284.4 & 253.7 & $12.10 \%$ & 15.89 & 7003.54 & 756.01 & $18.63 \%$ \\
\hline 279.7 & 234 & $19.53 \%$ & 16.8 & 7416.31 & 1211.75 & $29.86 \%$ \\
\hline
\end{tabular}

Table B14: Moisture Content for Phase 1 Probe, 59' Cable, Uncompacted Native Soil

\begin{tabular}{|c|c|c|c|c|c|c|}
\hline M of Wet Soil & M of Solids & $\begin{array}{c}\text { Moisture } \\
\text { Content }(\mathrm{w})\end{array}$ & $\begin{array}{c}\text { Total Mass } \\
(\mathrm{bs})\end{array}$ & Total Mass (g) & V of Water & Volumetric w \\
\hline 136.8 & 134.8 & $1.48 \%$ & 13.68 & 6205.21 & 90.72 & $2.24 \%$ \\
\hline 175.6 & 167.8 & $4.65 \%$ & 12.29 & 5574.71 & 247.62 & $6.10 \%$ \\
\hline 96 & 90.4 & $6.19 \%$ & 12.09 & 5483.99 & 319.90 & $7.88 \%$ \\
\hline 118.2 & 108.7 & $8.74 \%$ & 14.83 & 6726.84 & 540.65 & $13.32 \%$ \\
\hline 178.9 & 160.1 & $11.74 \%$ & 15.68 & 7112.40 & 747.42 & $18.42 \%$ \\
\hline 246.9 & 213.7 & $15.54 \%$ & 16.83 & 7634.04 & 1026.53 & $25.29 \%$ \\
\hline
\end{tabular}

Table B15: Moisture Content for Phase 1 Probe, 82' Cable, Uncompacted Native Soil

\begin{tabular}{|c|c|c|c|c|c|c|}
\hline M of Wet Soil & M of Solids & $\begin{array}{c}\text { Moisture } \\
\text { Content (w) }\end{array}$ & $\begin{array}{c}\text { Total Mass } \\
(\mathrm{lbs})\end{array}$ & Total Mass (g) & V of Water & Volumetric w \\
\hline 136.8 & 134.8 & $1.48 \%$ & 13.68 & 6205.21 & 90.72 & $2.24 \%$ \\
\hline 175.6 & 167.8 & $4.65 \%$ & 12.29 & 5574.71 & 247.62 & $6.10 \%$ \\
\hline 96 & 90.4 & $6.19 \%$ & 12.09 & 5483.99 & 319.90 & $7.88 \%$ \\
\hline 118.2 & 108.7 & $8.74 \%$ & 14.83 & 6726.84 & 540.65 & $13.32 \%$ \\
\hline 178.9 & 160.1 & $11.74 \%$ & 15.68 & 7112.40 & 747.42 & $18.42 \%$ \\
\hline 246.9 & 213.7 & $15.54 \%$ & 16.83 & 7634.04 & 1026.53 & $25.29 \%$ \\
\hline
\end{tabular}


Table B16: Moisture Content for Phase 1 Probe, 98' Cable, Uncompacted Native Soil

\begin{tabular}{|c|c|c|c|c|c|c|}
\hline M of Wet Soil & M of Solids & $\begin{array}{c}\text { Moisture } \\
\text { Content }(\mathrm{w})\end{array}$ & $\begin{array}{c}\text { Total Mass } \\
(\mathrm{lbs})\end{array}$ & Total Mass (g) & V of Water & Volumetric w \\
\hline 160.2 & 156.4 & $2.43 \%$ & 13.67 & 6200.67 & 147.08 & $3.62 \%$ \\
\hline 84.4 & 80 & $5.50 \%$ & 13.3 & 6032.84 & 314.51 & $7.75 \%$ \\
\hline 158.3 & 145.7 & $8.65 \%$ & 12.56 & 5697.18 & 453.47 & $11.17 \%$ \\
\hline 114.3 & 102.5 & $11.51 \%$ & 15.85 & 7189.51 & 742.22 & $18.29 \%$ \\
\hline 159.7 & 139 & $14.89 \%$ & 15.63 & 7089.72 & 918.96 & $22.64 \%$ \\
\hline
\end{tabular}

Table B17: Moisture Content for Phase 1 Probe, 120' Cable, Uncompacted Native Soil

\begin{tabular}{|c|c|c|c|c|c|c|}
\hline M of Wet Soil & M of Solids & $\begin{array}{c}\text { Moisture } \\
\text { Content (w) }\end{array}$ & $\begin{array}{c}\text { Total Mass } \\
(\mathrm{lbs})\end{array}$ & Total Mass (g) & V of Water & Volumetric w \\
\hline 127.3 & 125.1 & $1.76 \%$ & 13.46 & 6105.42 & 105.51 & $2.60 \%$ \\
\hline 110.2 & 104.6 & $5.35 \%$ & 13.11 & 5946.66 & 302.19 & $7.45 \%$ \\
\hline 126 & 115.1 & $9.47 \%$ & 13.29 & 6028.30 & 521.50 & $12.85 \%$ \\
\hline 209.8 & 186.4 & $12.55 \%$ & 14.94 & 6776.74 & 755.84 & $18.62 \%$ \\
\hline 208.3 & 180.1 & $15.66 \%$ & 16.51 & 7488.89 & 1013.86 & $24.98 \%$ \\
\hline
\end{tabular}

Table B18: Moisture Content for Phase 1 Probe, 138' Cable, Uncompacted Native Soil

\begin{tabular}{|c|c|c|c|c|c|c|}
\hline M of Wet Soil & M of Solids & $\begin{array}{c}\text { Moisture } \\
\text { Content (w) }\end{array}$ & $\begin{array}{c}\text { Total Mass } \\
(\mathrm{lbs})\end{array}$ & Total Mass (g) & V of Water & Volumetric w \\
\hline 83.9 & 80.3 & $4.48 \%$ & 11.5 & 5216.37 & 223.82 & $5.52 \%$ \\
\hline 199.6 & 186.8 & $6.85 \%$ & 12.48 & 5660.89 & 363.02 & $8.95 \%$ \\
\hline 127 & 115.5 & $9.96 \%$ & 13.72 & 6223.35 & 563.53 & $13.89 \%$ \\
\hline 145.8 & 128.5 & $13.46 \%$ & 16.14 & 7321.06 & 868.68 & $21.40 \%$ \\
\hline 208.7 & 175.3 & $19.05 \%$ & 16.86 & 7647.65 & 1223.92 & $30.16 \%$ \\
\hline
\end{tabular}

Table B19: Moisture Content for Phase 2 Probe, All Cables, Compacted Native Soil

\begin{tabular}{|c|c|c|c|c|c|c|}
\hline M of Wet Soil & M of Solids & $\begin{array}{c}\text { Moisture } \\
\text { Content (w) }\end{array}$ & $\begin{array}{c}\text { Total Mass } \\
(\mathrm{bs})\end{array}$ & Total Mass (g) & V of Water & Volumetric w \\
\hline 170.1 & 168 & $1.25 \%$ & 78.63 & 35667 & 440.33 & $2.15 \%$ \\
\hline 379.5 & 362.6 & $4.66 \%$ & 78.57 & 35640 & 1587.13 & $7.75 \%$ \\
\hline 224.8 & 210.8 & $6.64 \%$ & 85.41 & 38743 & 2412.82 & $11.77 \%$ \\
\hline 596 & 536.3 & $11.13 \%$ & 93.48 & 42892 & 4296.40 & $20.97 \%$ \\
\hline 248.2 & 215.9 & $14.96 \%$ & 95.6 & 42823 & 5572.86 & $27.20 \%$ \\
\hline
\end{tabular}


Table B20: Moisture Content for Phase 2 Probe, All Cables, Sand

\begin{tabular}{|c|c|c|c|c|c|c|}
\hline M of Wet Soil & M of Solids & $\begin{array}{c}\text { Moisture } \\
\text { Content (w) }\end{array}$ & $\begin{array}{c}\text { Total Mass } \\
(\mathrm{bs})\end{array}$ & Total Mass (g) & V of Water & Volumetric w \\
\hline 146.3 & 144.3 & $1.39 \%$ & 78.76 & 35800 & 489.41 & $2.39 \%$ \\
\hline 229.4 & 219.3 & $4.61 \%$ & 76.15 & 34615 & 1524.03 & $7.44 \%$ \\
\hline 252.8 & 236.3 & $6.98 \%$ & 80.00 & 36365 & 2373.51 & $11.58 \%$ \\
\hline 214.7 & 194.2 & $10.56 \%$ & 84.77 & 38531 & 3679.02 & $17.95 \%$ \\
\hline 344.3 & 297.9 & $15.58 \%$ & 89.89 & 40858 & 5506.28 & $26.87 \%$ \\
\hline
\end{tabular}

Table B21: Moisture Content for Phase 2 Probe, All Cables, Uncompacted Native Soil

\begin{tabular}{|c|c|c|c|c|c|c|}
\hline M of Wet Soil & M of Solids & $\begin{array}{c}\text { Moisture } \\
\text { Content (w) }\end{array}$ & $\begin{array}{c}\text { Total Mass } \\
(\mathrm{lbs})\end{array}$ & Total Mass (g) & V of Water & Volumetric w \\
\hline 136.4 & 134.7 & $1.26 \%$ & 74.74 & 33971 & 423.39 & $2.07 \%$ \\
\hline 148.7 & 142.3 & $4.50 \%$ & 71.40 & 32455 & 1396.85 & $6.82 \%$ \\
\hline 218.3 & 204.4 & $6.80 \%$ & 76.51 & 34775 & 2214.26 & $10.81 \%$ \\
\hline 189 & 171.5 & $10.20 \%$ & 85.79 & 38997 & 3610.83 & $17.62 \%$ \\
\hline 256.9 & 222 & $15.72 \%$ & 92.04 & 41837 & 5683.58 & $27.74 \%$ \\
\hline
\end{tabular}




\section{DISTRIBUTION:}

1 Willis Stewart

AGEC Inc.

2019 Butler Loop

Richland, WA 99352

1 Ralph Gruebel

AGRA Earth \& Environmental, Inc. 4700 Lincoln Rd., N.E.

Albuquerque, NM 87109

1 Brent Lewis

Bureau of Land Management

Denver Service Center

Bldg. 50

Denver, CO 80225-0047

1 Stephanie Odell

Bureau of Land Management

Farmington District Office

1235 LaPlata Highway

Farmington, NM 87401

1 Larry Stebbins

FERMCO

MS: $81-2$

P.O. Box 538704

Cincinnati, OH 45235

1 Kevin Kostelnick

Idaho National Engineering \&

Environmental Lab

Lockheed Martin Idaho Technologies

P.O. Box 1625

Idaho Falls, ID 83415-3710

1 Wayne Downs

Idaho National Engineering \&

Environmental Lab

P.O. Box 1625

Idaho Falls, ID 83415-2110
1 Jim Studer

Intera, Inc.

1650 University Blvd. N.E.

Albuquerque, NM 87102

1 Cindy Ardito

Intera, Inc.

1650 University Blvd. N.E.

Albuquerque, NM 87102

1 Joe Shinn

Lawrence Livermore National Laboratory

MS L453

P.O. Box 808

Livermore, CA 94551-9900

1 Earl Whitney

Los Alamos National Laboratory

EES-5, MS F665

Los Alamos, NM 87545

1 Kay Birdsell

Los Alamos National Laboratory

EES-5, MS F665

Los Alamos, NM 87545

1 Rosenberg Nina

Los Alamos National Laboratory

EES-DO, MS D446

Los Alamos, NM 87545

1 Steven Limback

Los Alamos National Laboratory

ESA-EPE, MS J576

Los Alamos, NM 87545

1 Bruce Erdal

Los Alamos National Laboratory

EM-TD, MS J591

Los Alamos, NM 87545 
1 Eric Rogoff

MDM/Lamb, Inc.

6121 Indian School Rd., N.E.

Suite 105

Albuquerque, NM 87110

1 Andrea Hart

MSE Technology Applications, Inc.

P.O. Box 4078

Butte, MT 59702

1 Creighton Barry

MSE Technology Applications, Inc.

P.O. Box 4078

Butte, MT 59702

1 Dave Emilia

MSE Technology Applications, Inc.

P.O. Box 4078

Butte, MT 59702

1 Robert Andrews, Ph.D.

National Research Council

National Academy of Science

Board of Radioactive Waste Management

2001 Wisconsin Ave., N.W.

Washington, DC 20007

1 New Mexico Junior College

Pannell Library

Lovington Highway

Hobbs, NM 88240

1 New Mexico State Library

325 Don Gaspar

Santa Fe, NM 87503

1 New Mexico Tech

Martin Speere Memorial Library

Campus Street

Socorro, NM 87810
1 J. Espinosa

NM Environment Department

1190 St. Francis Drive

Santa Fe, NM 87503-0968

1 Elizabeth Fiedler

Oak Ridge National Laboratory

P.O. Box 2008

Oak Ridge, TN 37831-6317

1 Tom Early

Oak Ridge National Laboratory

P.O. Box 2008

Oak Ridge, TN 37831-6317

1 Cindy Kendrick

Oak Ridge National Laboratory

P.O. Box 2001, EW-923

Oak Ridge, TN 37831

1 Kirk Cantrell

Pacific Northwest National Laboratories

MS K6-81

P.O. Box 999

Richland, WA 99352

1 Phillip Gauglitz

Pacific Northwest National Laboratories

Battelle Blvd.

P.O. Box 999

Richland, WA 99352

1 Steve Slate

Pacific Northwest National Laboratories

Battelle Blvd.

P.O. Box 999

Richland, WA 99352

1 Sandy Dalvit-Dunn

Science \& Engineering Assoc., Inc.

3205 Richards Lane

Suite A

Santa Fe, NM 87505 
1 Bill Lowry

Science \& Engineering Assoc., Inc. 3205 Richards Lane

Suite A

Santa Fe, NM 87505

1 Andrew Murray

SubTerra Remedial Engineers, Inc. 1820 Bering Drive

Suite 23

San Jose, CA $95112-4212$

1 Cheryl Allen Tech Reps, Inc. 5000 Marble N.E. Albuquerque, NM 87110

1 D. Dresp Thomas Branigan Library 106 W. Hadley St.

Las Cruces, NM 88003

1 Marvin Gross

U.S. Department of Energy

Fernald Field Office

P.O. Box 538704

Cincinnati, OH 45253-8704

1 Johnny Moore

U.S. Department of Energy

Oak Ridge Operations Office

EW-923

P.O. Box 2001

Oak Ridge, TN 37831-8620

1 Elisabeth Reber-Cox

U.S. Department of Energy

Oakland Operations Office

Room $700 \mathrm{~N}$

1301 Clay Street

Oakland, CA 94612-5208
1 Helen Stolz

U.S. Department of Energy

Nevada

P.O. Box 98518

Las Vegas, NV 89193-8518

1 Gillian Eaton

U.S. Department of Energy

Rocky Flats

Tech Site, Bldg. T124A

P.O. Box 928

Golden, CO 80402-0928

1 Shannon Saget

U.S. Department of Energy

Richland Operations Office

P.O. Box 550, K8-50

Richland, WA 99352

1 Skip Chamberlain

U.S. Department of Energy, EM-53

Cloverleaf Building

19901 Germantown Rd.

Germantown, MD 20874-1290

1 Mel Shupe

U.S. Department of Energy

Federal Energy Technology Center

Industrial Park

P.O. Box 3462

Butte, MT 59702

1 Bob Bedick

U.S. Department of Energy

Federal Energy Technology Center 3610 Collins Ferry Rd.

Morgantown, WV 26507-0880

1 Dale Pflug

U.S. Department of Energy

Chicago Operations Office

EAD/900

9800 South Cass Ave.

Argonne, II 60439-4832 
1 Doug Maynor

U.S. Department of Energy

Ohio Operations Office

P.O. Box 3020

Miamisburg, $\mathrm{OH}$ 45343-3020

1 Thomas Williams

U.S. Department of Energy

Idaho Operations Office

MS1219

785 DOE Pl.

Idaho Falls, ID 83402

1 Richard Baker

U.S. Department of Energy

Chicago Operations Office

9800 South Cass Ave.

Argonne, IL 60439

1 Paul Beam

U.S. Department of Energy, EM-40

Cloverleaf Building

19901 Germantown Rd.

Germantown, MD 20874-1290

1 Kim Abott

U.S. Department of Energy

Oakland Operations Office

Room $700 \mathrm{~N}$

1301 Clay Street

Oakland, CA 94612-5208

1 Dennis Green

U.S. Department of Energy

Idaho Operations Office

850 Energy Drive

Idaho Falls, ID 83401-1563

1 Dennis Olona

U.S. Department of Energy

Albuquerque Operations Office

P.O. Box 5400

Albuquerque, NM 87185
1 Paul Zielinski

U.S. Department of Energy, EM-443

Cloverleaf Bldg.

19901 Germantown Rd.

Germantown, MD 20874-1290

1 James Wright

U.S. Department of Energy

Savannah River Operations Office

Bldg. 703-46A

P.O. Box A

Aiken, SC 29803

1 Bill Wilborn

U.S. Department of Energy

Nevada Operations Office

2753 S Highland Rd.

Las Vegas, NV 89109

1 Phillip Washer

U.S. Department of Energy

Savannah River Operations Office

Bldg. 773-A

P.O. Box 616

Aiken, SC 29803

1 Jef Walker

U.S. Department of Energy, EM-53

Cloverleaf Bldg.

19901 Germantown Rd.

Germantown, MD 20874-1290

1 George Schneider

U.S. Department of Energy

Idaho Operations Office

785 DOE Place

Idaho Falls, ID 83402

1 Elizabeth Phillips

U.S. Department of Energy

Oak Ridge Operations Office

P.O. Box 2001

Oak Ridge, TN 37830 
1 Rod Warner

U.S. Department of Energy

Ohio Operations Office

P.O. Box 538705

Cincinnati, $\mathrm{OH} 45030$

1 Scott McMullin

U.S. Department of Energy

Savannah River Operations Office

Bldg. 703-46A

P.O. Box A

Aiken, SC 29802

1 Julianne Levings

U.S. Department of Energy

Albuquerque Operations Office

P.O. Box 5400

Albuquerque, NM 87185

1 Jeff Lenhert

U.S. Department of Energy

Albuquerque Operations Office

P.O. Box 5400

Albuquerque, NM 87185

1 Chuck Morgan

U.S. Department of Energy

Nevada Operations Office

2753 S. Highland Rd.

Las Vegas, NV 89109

1 Thomas Hicks

U.S. Department of Energy

Savannah River Operations Office

Bldg. 703-46A

P.O. Box A

Aiken, SC 29802

1 Maria Vargas

U.S. Department of Energy

Richland Operations Office

P.O. Box 550

Richland, WA 99352
1 James Paulson

U.S. Department of Energy

Chicago Operations Office

9800 South Cass Ave.

Argonne, IL 60439

1 Gary Huffman

U.S. Department of Energy

Rocky Flats Office

Highway 93rd \& Cactus St.

Golden, CO 80402

1 Sharon Johnson

U.S. Department of Energy

Savannah River Operations Office

703 A, Rm. B202

Aiken, SC 29802

1 John Geiger

U.S. Department of Energy

Savannah River Operations Office

P.O. Box A

Aiken, SC 29802

1 Arturo Palomares

U.S. Environmental Protection Agency

Region 8

999 18th Street

Suite 500

Denver, CO 80202

1 John Stormont

University of New Mexico

Dept. of Civil Engineering

Albuquerque, NM 87131-1351

1 University of New Mexico

Zimmerman Library

Government Publications Department

Albuquerque, NM 87131

1 Bruce Thompson

University of New Mexico

Dept. of Civil Engineering

Albuquerque, NM 87131-1351 
1 David Daniel

University of Texas at Austin

Dept. of Civil Engineering

Cockrell Hall, Room 9.102

Austin, TX 78712

1 Thomas Gaughan

Westinghouse Savannah River Company

Savannah River Technology Center

Environmental Sciences Section

P.O. Box 616/730-2B

Aiken, SC 29802

1 Michael Serrato

Westinghouse Savannah River Company

Savannah River Technology Center

Environmental Sciences Section

P.O. Box 616/773-42A

Aiken, SC 29802

1 Tim Jarosch

Westinghouse Savannah River Company

Bldg. 773-42A

Road SR-1

Aiken, SC 29808

1 Pete Zionkowski

Westinghouse Savannah River Company

Savannah River Technology Center

Environmental Sciences Section

P.O. Box 616/730-2B

Aiken, SC 29802

1 Brian Looney

Westinghouse Savannah River Company

Bldg. 773-42A

Road SR-1

Aiken, SC 29808

1 Ahmet Seur

Westinghouse Savannah River Company

Savannah River Technology Center

Environmental Sciences Section

P.O. Box $616 / 730-2 B$

Aiken, SC 29802
1 MS0701 Richard Lynch, 6100

10719 George Allen, 6621

250719 Thomas Burford, 6621

10719 Stephen Dwyer, 6621

10719 Jesus Lopez,6621

10719 J. Christopher Sears, 6621

10724 Joan Woodard, 6000

10968 James Swanson, 5716

11147 Warren Cox, 6681

11147 Fran Nimick, 6682

11148 Dick Fate, 6685

11148 Jerry Peace, 6685

20619 Review \& Approval Desk for DOE/OSTI, 12690

50899 Technical Library, 4916

19018 Central Technical Files, 8940-2 